\title{
Variables, Dimensions, and Indicators Important to Develop the Multidimensional Poverty Line Measurement in Indonesia
}

\author{
Carunia Mulya Firdausy ${ }^{1}$ (D) Dwi Andayani Budisetyowati ${ }^{2}$
}

Accepted: 2 December 2021 / Published online: 26 January 2022

(c) The Author(s), under exclusive licence to Springer Nature B.V. 2021

\begin{abstract}
Criticism on the use of the income/expenditure poverty line to estimate the number of the poor in Indonesia leads to questioning the use of the multidimensional poverty line (MPL) measurement. While current research on the defining variables, dimensions, and indicators to develop the MPL measurement in Indonesia was not based on direct views of the poor and the non-poor household heads, we complement this research gap by examining it based on direct views of the poor and the non-poor household heads. Methods used to collect the empirical data were conducted in four stages. The first stage was by organizing a Focus Group Discussion with twenty-five participants. The second stage was by conducting a pilot for the main survey on thirty poor and non-poor household heads. The third stage was by distributing the main survey questionnaire to 274 non-poor and 315 poor household head respondents in six representative locations in Indonesia. The fourth stage was by taking in-depth interviews with 8-12 key informants in each survey location. These data were further analysed by employing the qualitative technique. The results confirmed that the poor and the non-poor household head respondents, and the interviewees under the survey viewed the MPL measurement as a comprehensive and better poverty measurement. However, dimensions and indicators that were viewed to be important in developing the MPL measurement were mostly in the groups of three variables. These three variables were capability, empowerment, and opportunity. These three variables should be no hierarchy of importance in developing the MPL measurement as well as in formulating policy and programs to eradicate the incidence of poverty in Indonesia.
\end{abstract}

Keywords Income Expenditure poverty line $\cdot$ Multidimensional poverty line Empowerment $\cdot$ Capability $\cdot$ Opportunity $\cdot$ Security

Carunia Mulya Firdausy

cmfirdausy@gmail.com

Dwi Andayani Budisetyowati

Dandayani24@yahoo.com

1 Faculty of Economics and Business and Center for Economic Research, University of Tarumanagara and Indonesian Institute of Science, West Jakarta 11440, Indonesia

2 Faculty of Law Pakuan University Bogor, Bogor city, 16129, Indonesia 


\section{Introduction}

The Covid-19 pandemic that spread since early March of 2020 made Indonesia's economy fall into a recession. In two consecutive quarters of the second and the third quarter of 2020, the growth rates contracted to minus 5.32 percent and minus 3.49 percent respectively. In the fourth quarter of 2020, it improved slightly to minus 2.19 percent. For the year 2020, the economic growth rate was estimated at minus 2.07 percent. In the first quarter of 2021, however, the growth rate was still minus 0.74 (CBS 2021).

One of the consequences of the recession is the increase in the proportion of the poor. In September 2019, the proportion of the poor before the Covid-19 pandemic was recorded at 9.22 percent covering 24.79 million people. In September 2020, however, the percentage of the poor increased to 10.19 percent involving 27.55 million people, out of a population of 270.2 million -turning back three years of progress in poverty reduction (CBS 2021). The increase of the poor by almost 1 percent or by 2.76 million people in these two periods was partly because the Covid-19 pandemic forces the government of Indonesia to restrict the large-scale social movement of the population. This policy causes people to do less contact economic (LCE) activities. As a result, many economic activities that require the physical presence of workers cannot operate, and a large portion of the public was unemployed and lost their income. The informal sector as the main source of income for the poor was no exception (Bambang Brodjonegoro, 2020; Ma'ruf Amin, 2021; World Bank, 2020).

However, the method to estimate the incidence of poverty was still based on the official conventional absolute income/expenditure poverty line established by CBS. The official income/expenditure poverty line used in 2020, for example, was about Rp. 458,947 per capita/month (or roughly at US\$ 31/capita/month). This was composed of two, namely, 73.9 percent for food spending and the rest of 26.1 percent for non-food spending (CBS 2021).

This absolute income/expenditure poverty line measurement has also been used in many countries. In China, for instance, by using the World Bank absolute poverty line of US \$ 1.90 PPP per capita per day (in constant prices of 2011), the proportion of the poor decreased from 17.2 percent in 2010 to 0.6 percent in 2019 . However, if the absolute poverty line used was the US \$ 3.2 per capita per day, the poor in China was about 5.4 percent in 2019 (Knoema, 2020). This suggests that there is no evidence of countries successfully using the poverty lines to eradicate the incidence of poverty.

The above one-dimensional method is criticized by many scholars (see, for instance, Anand et al., 2009; Artha \& Dartanto, 2018; ADB 2014; Garcia-Perez et al. 2017; Ke-Mei \& Te-Mu, 2019; Kingdon \& Knight, 2004; Li et al., 2019; Pomati \& Nandy, 2020; Ravallion, 1992; Sen, 1999; Tsui, 2002; World Bank, 2001) as well as by the poor themselves in Indonesia (Asra, 2011; Firdausy, 2017, 2020).

It was argued the above income/expenditure poverty line is an imperfect way to measure the number of the poor in Indonesia. This is because it does not reflect the true living standards of the poor. The line does not take into account the updated consumption data specific to Indonesia's poor, markets for basic needs and public goods, the impact of volatile and rising costs associated with food insecurity, and the increasing vulnerability to natural disasters (including Covid-19 pandemic), climate change, economic crisis, and other shocks (Artha \& Dartanto, 2018; ADB 2014; Firdausy, 2015, 2020).

ADB (2014, p. 43), for example, criticized this line by stating as follows.

"Money-metric measures do not provide a complete picture of well-being for either

individuals or households. Other dimensions need to be taken into account. Money 
means little when there is market failure-or where markets simply do not exist. Non-monetary poverty tends to be more persistent than monetary poverty. For example, once a child is stunted, it is almost irreversible regardless of how the income status of the person evolves. The same can be said about education-most school dropouts remain poor in terms of human capital, even if some may grow rich later in life".

Similarly, Sen (1999) has demonstrated how poverty is much more than simply being unable to feed oneself and one's family. People, wherever they are in the world, value the ability to participate in customary social activities and to be able to meet expected social norms. For a deeper insight to show the level of agreement between the different criticisms of the MPL measurement and the uni-dimensional income/expenditure poverty measurement can be seen, for example, in Pomati and Nandi (2020) and the references therein.

Given the above criticisms on the use of the absolute income/expenditure poverty line, the reliability of the estimation of the proportion of the poor amidst the Covid-19 pandemic in 2020 and before this year in Indonesia was questioned at least by scholars (Artha \& Dartanto, 2018; Asep Suryahadi et al., 2021; Asra, 2011; Firdausy, 2015, 2020; Ridho Al Izzati, 2021). They argue the official estimation of the incidence of poverty in Indonesia is only true in terms of the income/expenditure statistical figures, but not in terms of the requirement to maintain a minimum living standard by the poor. Due to this reason, the government of Indonesia (GOI) led by the Ministry of National Planning Board (BAPPENAS) seeks other comprehensive and better alternative poverty lines that are more suitable and reliable to represent the real or the true needs of life of the poor.

One of the alternatives advanced in the literature is the use of the subjective or self-rated poverty approach (Dolan et al., 2011; Firdausy, 2012; Kingdon \& Knight, 2004; Mangahas, 2008). Mangahas (2008), for instance, highlighted that the subjective poverty line is the world's most rapid and most up-to-date system for statistical monitoring of poverty and hunger in a country at the national level. This approach is not only simple, but it is also easy to be implemented, and quicker as it is developed based on individual perception or opinion toward the definition of the poor. This method has been also applied in the Netherland (Goedhart, 1977) as well as in China (Gustafsson \& Yue, 2006) and the Philipines (Mangahas, 2008). In the Philippines, for instance, this method has been used by the Social Weather Station (SWS) since 1983 to complement the poverty data collected by the National Statistical Coordination Board, Philippines (Mangahas, 2008). In China, it was found the use of this method has not been much different from the estimate of the poor using the World Bank's poverty line (Gustafsson \& Yue, 2006).

In Indonesia, however, Artha and Dartanto (2018), Firdausy et al., (2013, 2015, 2016); and Ridwan (2019) from their empirical studies found that the poor and the non-poor viewed the use of the subjective or self-rated poverty line as inappropriate in measuring the incidence of poverty. This is partly because the self-rated poverty line proposed by the poor and the non-poor household head respondents differed not only within the same poor groups but also between the poor and the non-poor. These differences may occur as the consequences of differences in socio-cultural (e.g. educational attainment and ethnic origins), demographic (e.g. age), and economic (e.g. income/expenditure level) as well as geographical locations (e.g. rural versus urban areas).

The above criticism leads to further suggestions advanced in the literature to the use of the multidimensional poverty measurement including the multidimensional poverty 
Indices-MPI $^{1}$ (see, for instance, Alkire \& Santos, 2010, 2013; Alkire \& Summer, 2013; Alsop \& Heinsohn, 2005; Clark, 2005; Garcia-Perez et al., 2017; Ke-Mei et al., 2019; Li et al., 2019; Lustig \& Stern, 2000; Pomati \& Nandy, 2020; Sen, 1999; Van Praag \& Carbonel, 2006; World Bank, 2001).

The increasing concern to establish the MPL measurement in Indonesia is partly due to the fact of the estimated figure of the incidence of poverty in Indonesia made by the World Bank in 2018 was found to be significantly different from the estimated figure made by the Indonesian Central Board of Statistics (CBS). The estimated number of the poor made by the World Bank in 2018 was found to be almost three times higher than the estimated figure of the poor made by the CBS (see, for instance, Artha \& Dartanto, 2018; Ningrum et al., 2019; Ridwan, 2019).

Artha and Dartanto (2018), Ningrum et al. (2019), and Ridwan (2019) further conducted studies to establish dimensions and indicators of multidimensional poverty measurement in Indonesia. They identified three dimensions that need to be accommodated in defining the multidimensional poverty measurement, namely, education, health, and the quality of life. Of these three dimensions, eleven indicators were then proposed by these studies in establishing the multidimensional poverty line (MPL). ${ }^{2}$ These indicators include nutrition sufficiency, educational access, housing, schooling, sanitation, clean water, and electricity. They found that if these eleven indicators were used to estimate the incidence of poverty in Indonesia, the estimated figure of the poor population in 2018 was almost the same as the estimated figure made by the World Bank. Similar to these studies, there was another study conducted by the Indonesian Ministry of Housing and Public Works. However, this study proposed seven indicators in developing the MPL, namely, the quality of housing, sanitation, clean water, road access, drainage, wastes, and fire protection. This study argued that these seven indicators are necessary to be included in developing the MPL in Indonesia (see, Ridwan, 2019 for details).

Due to the above empirical studies, the Ministry of Development Planning (BAPPENAS) in cooperation with the CBS from 2016 to 2018 organized a serial discussion in reexamining variables, dimensions, and indicators' importance in developing the MPL. The results of this serial discussion, however, confirmed that dimensions and indicators identified as important in developing the MPL measurement by the above empirical studies cannot be fully justified. The reason is partly that the dimensions and indicators identified as important to develop the MPL measurement were subjectively made by the authors above. In other words, the proposed dimensions and indicators of importance to develop the MPL measurement in the above studies were not purely based on the subjective perceptions or views/opinions of the poor and the non-poor in Indonesia.

\footnotetext{
1 MPI indicates multiple deprivations at the household and individual level in health, education and standard of living. A household is identified as multidimensionally poor, if and only if, it is deprived in some combination of 10 indicators whose weighted sum exceeds 30 percent of deprivations. The MPI reflects both the incidence of multidimensional deprivation (a headcount of those in multidimensional poverty) and its intensity (the average deprivation score experienced by poor people). For detail, see, Alkire \& Santos (2010).

2 The MPL in this study is defined as the line that accommodates dimensions and indicators of four variables advanced in the literature, namely, capability (Sen, 1999), empowerment, opportunity and security (World Bank 2001). However, this present study limits the focus only determining variables, dimensions and indicators directly considered important by the poor and the non-poor household head respondents and interviewees in developing the MPL. Thus, no estimation or measurement yet to determine the MPL.
} 
As there have been no studies yet proposing variables, dimensions, and indicators that are important to develop the MPL measurement directly based on subjective perceptions of the poor and the non-poor in Indonesia, this study aims at filling this research gap. By determining the importance of variables, dimensions, and indicators directly from the poor and the non-poor household heads, the MPL measurement can be further developed to complement and/or substitute the official income/expenditure poverty line. So that, a better and comprehensive policy to alleviate the longstanding problems of poverty in Indonesia can be introduced by the government of Indonesia. These are the added and the originality values of the study.

The study is structured as follows. Section 2 presents the detailed stages of the methods to collect and analyse the data. Section 3 shows the results of the study, including the results of FGD, a pilot for the main survey, the main survey questionnaire, and an in-depth interview to collect views or opinions of the variables, dimensions, and indicators needed to develop the MPL measurement, the importance of the MPL to replace the income/ expenditure poverty line, and whether or not there should be a hierarchy of importance of the four variables in developing the MPL. Section 4 discusses the results, conclusions, and implications of the study.

\section{Data and Methods}

The study began by reviewing the literature on the MPL measurement. Of the many studies, it was examined that studies by Sen (1999) and the World Bank (2001) relatively provided a more complete detailed picture of variables, dimensions, and indicators ${ }^{3}$ of the MPL measurement. These variables, dimensions, and indicators have also been considered appropriate to reflect the socio-economic and cultural conditions of the people in Indonesia (Asra, 2011). These variables are capability proposed by Sen (1999), and empowerment, opportunity, and security proposed by the World Bank (2001). These four variables, their dimensions, and their indicators were therefore used as the conceptual basis for further developing instruments in the study.

After deciding the above conceptual basis of the study, the following four studies to collect empirical data were conducted.

\subsection{Study 1}

In this study 1, we organized the Focus Group Discussion (FGD). There were twenty-five participants invited to this FGD. It involved the government officials from the Ministry of Development Planning (BAPPENAS), the Central Board of Statistics (CBS), academicians (including researchers) from the University of Indonesia, from the Centre for Economic Research, from the Centre for Manpower and Population Research-Indonesian Institute of Sciences, and the officials of Non-government Organizations (NGOs) including SMERU Research Institute, Institute for Development of Economics and Finance (INDEF), and other participants from private universities and the poor household heads (see, Appendix 1 for detailed participants of FGD forum and the list of main questions for group discussion).

\footnotetext{
3 A variable defined here as a factor that has dimensions and indicators. Dimension is defined as a component of variable, while indicators are items that indicate the dimension.
} 
To make the FGD focus on the context and well-organized, four resource persons were invited to the FGD forum. These four resource persons were from the Ministry of Development Planning, the Central Board of Statistics, The SMERU Research Institute, and a Sociologist from the University of Indonesia. They were asked to deliver their views on five points as follows. First, to discuss the importance and objective of the study. Second, to gather views of the study unit analysis and instruments that need to be used in the study. Third, to determine variables, dimensions, and indicators that can be used to develop the MPL measurement in Indonesia. Fourth, to discuss whether or not variables, dimensions, and indicators proposed by Sen (1999) and the World Bank (2001) are relevant to establish the MPL measurement. Fifth, to discuss variables, dimensions, and indicators that can be used as materials for the survey instruments. Their presentations were then discussed by the participants of the FGD forum. The analysis procedures of this FGD were by analysing discussion materials and responses of the FGD participants.

\subsection{Study 2}

In Study 2, we carried out a pilot for the main survey. The objective of this pilot survey was to seek views of respondents on whether or not variables, dimensions, and indicators given in the questionnaire were important or not. Also, they were asked whether or not materials questions in the questionnaire were easy to be understood and clear. In addition, they were asked to give inputs, suggestions, or modifications to improve the pilot questionnaire that will be used for the main survey questionnaire. All the answers to those questions were then calculated, tabulated, and analysed for further improvement or changes (if any) that need to be made in the main survey questionnaire (Appendix 2). A total of 30 poor and non-poor household heads was conveniently selected in the capital city of Jakarta. This urban location was selected as the poor and the non-poor household heads relatively have different socio-economic and cultural backgrounds and because access to reach this location was less costly. The definition of household here was a group of people living and eating together from the same house.

\subsection{Study 3}

In Study 3, we distributed the main survey questionnaire to the sample respondents in the survey locations. There were three objectives of this main survey questionnaire. The first was to examine the views of respondents on variables, dimensions, and indicators considered important or not important in developing the MPL measurement. The second was to have respondents' views on whether or not the present income/expenditure poverty line is necessary to be replaced by the MPL measurement. The third was to examine respondents' views on whether a hierarchy of variables is important in developing the MPL measurement or not.

Before the main survey questionnaires were distributed to the respondents in the field survey, a consultation with the statistical officials of the CBS in Jakarta was organized. The purpose of this consultation was to get suggestions concerning representative survey locations and to determine the number of sample respondents in survey locations. The statistical officials of CBS suggested six survey locations based on locations' representativeness consideration. These six representative survey locations were in all three parts of Indonesia, namely, Western, Central, and Eastern parts. The survey location of the Western part was in the city of Padang (West Sumatra Province). In the Central part, it was in the rural 
areas in Semarang (Central Java Province) and Surabaya (East Java Province), and in the Capital city of Jakarta, and the city of Bogor (West Java Province). Whilst the survey location in the Eastern part of Indonesia was a rural area in the District Goa, Makassar (South Sulawesi Province). These six locations consist of three rural areas and three urban areas.

Given the number of the population in each survey location and by employing a simple random technique, 600 household heads were selected as sample respondents of the six survey locations. These respondents were then asked to categorize into the poor or the nonpoor household heads. This was done by asking them to select a card given to them that was written with the word poor or non-poor household head. The result showed that of 600 sample respondents, 326 respondents grouped themselves as the poor household heads, while the rest of 274 respondents categorized themselves as the non-poor household heads.

The main survey questionnaires were then distributed to the above 600 samples of the poor and the non-poor household head respondents in six survey locations (see, Appendix 3 for the main survey questionnaire). However, of 600 sample respondents, there were 589 household head respondents in six survey locations who completed the main survey questionnaires. This was composed of 315 questionnaires from the poor household head respondents and 274 questionnaires from the non-poor household head respondents. The brief profile of respondents in six locations under the survey was as follows. First, by sex category, the majority of respondents were male. The poor male respondents were about 76.8 percent, whilst the non-poor male respondents were 96.7 percent.

Second, the age profile of the poor was dominated by the age group between 35 and 60 years old. The proportion under these age groups was about 93.7 percent. The rest of 6.7 percent of the poor household heads was in the age group between 25 and 35 years old. For the non-poor household head respondents, about 78.5 percent were in the age group above 45 years old. The rest of 21.5 percent was in the age group between 25 and 44 years old. Third, a large percentage of the poor household head respondents has less than Junior High School (94.6\%). Only 5.4 percent have an educational background at the senior high school level and above. For the non-poor household head respondents, only 41.9 percent have educational background less than Junior high school. The rest of 58.1 percent have educational attainment above Junior high school.

To distribute and collect the questionnaires, university students and the officials of the CBS in each survey location were involved. Before the questionnaire was given to them, training on related materials questioned in the questionnaire was organized for them. This was aimed to minimize any problems associated with questions asked, and language barriers to understanding materials questioned in the main questionnaire.

The analysis procedures of questionnaire data were by calculating and tabulating the proportion of the views on the important or not important of variables, dimensions, and indicators of MPL, on the importance or unimportance of the MPL to replace the income/ expenditure poverty line, and on the importance or not the importance of the hierarchy of variables to develop the MPL (Appendix 3). In other words, the analysis of questionnaire survey data did not group the important or the unimportant variables, dimensions, and indicators, etc.based on differences of respondents by locations, or by other respondents' identity. This is because this study aims to establish a list of variables, dimensions, and indicators of the MPL measurement. 


\subsection{Study 4}

In Study 4, we conducted an in-depth interview. The purposes of this in-depth interview were: (1) to have views from the interviewees on variables, dimensions, and indicators important or not important to establish the MPL measurement; (2) to discuss and seek explanations from the interviewees on the respondents' views of the main survey questionnaire. The number of interviewees for this in-depth interview varied from 8 to 12 persons depending on the survey location. These interviewees consisted of the head of a village, 3 community members, 2-3 poor household heads, and 2-3 non-poor household heads in each survey location. The interviewers of the in-depth interview include the authors and the CBS officials in the survey location who is in charge of poverty data collection. The data analysis procedure for this in-depth interview was by using content analysis in that any responses of the interviewees were analysed to answer research questions. Details of interview materials for interviewees in the survey location were given in Appendix 4.

\section{Results}

\subsection{Results of Focus Group Discussion Forum}

The results of the FGD forum were as follows. First, the forum agreed to the importance and objectives of the study. This is due to the fact of the growing skepticism of the use of the metrics income/expenditure poverty line in estimating the incidence of poverty in Indonesia. Also, the present income/expenditure poverty line was argued as no longer reliable to represent the true needs of the poor in Indonesia. As one participant of the forum, for example, remarked:

The significant decline of poverty in Indonesia over the last 21 years to single-digit cannot be justified only by using the metric poverty line. This is simply because the official income/expenditure poverty line does not reflect important capability, empowerment, opportunity, and security variables. Attempts of this study to examine the possibility of the MPL to complement or replace the income/expenditure poverty line is therefore useful. By conducting this study, there is a basis for the government of Indonesia to expand the definition and measurement of poverty in Indonesia. Thus, this study can contribute to establishing variables, dimensions, and indicators of the MPL measurement that have not been directly examined yet in Indonesia.

Second, the FGD forum further suggested the importance to seek directly views from both the poor and the non-poor household heads as the unit analysis of the study. This unit of study analysis was needed to balance views from both sides of the poor and the non-poor household heads in justifying variables, dimensions, and indicators important or not important in developing the MPL measurement. Whilst for the instruments in collecting the empirical data, the FGD forum suggested the use of a pilot survey questionnaire and main questionnaire, in-depth interview instruments, and field observations to explore directly the views of both the poor and the non-poor household heads.

Third, the FGD forum suggested the need to have references to determine variables, dimensions, and indicators of the MPL measurement. This is simply because the poor and the non-poor household heads will have difficulties defining details of variables, dimensions, and indicators of the MPL measurement but more importantly because their views 
have no scientific justification to develop the MPL measurement. For that reason, the variables, dimensions, and indicators of the MPL measurement proposed by Sen (1999) and the World Bank (2001) are employed as the conceptual basis of this study. As pointed out by the government official who is in charge as the Director of Poverty at the Ministry of Development Planning, Director of SMERU Research Centre, and a Professor of Sociology from the University of Indonesia who have expertise in poverty studies as follows.

It is true that the poverty line based only on money metric does not reflect the importance of non-material, social and other dimensions of poverty. Efforts made to expand the definition and measurement of poverty in Indonesia are needed. Variables, dimensions, and indicators of the MPL measurement proposed by Sen (1999) and World Bank (2001) are useful references to be examined as the basis for developing the MPL measurement in Indonesia.

Therefore, the FGD forum supports the importance of this study and agreed to seek direct views from both the poor and the non-poor household heads as the unit analysis of the study. They also suggested the use of questionnaires, in-depth interview instruments, and field observations as the instruments to explore directly the views of both the poor and the non-poor household heads in the study. The variables, dimensions, and indicators proposed by Sen (1999) and the World Bank (2001) were also agreed to be employed as scientific justification in establishing the MPL measurement in Indonesia.

\subsection{Results of the Pilot for the Main Survey}

The results of the pilot survey questionnaire given to thirty urban poor and non-poor respondents in the capital city of Jakarta confirmed that the materials questioned in the questionnaire were easy to be answered. They also have no questions, suggestions, or modifications made to the given questionnaire of the pilot survey. These findings indicate that variables, dimensions, and indicators questioned in the pilot survey questionnaire were viewed as important in establishing the MPL measurement. The detailed results of the views given by the pilot survey respondents for variables, dimensions, and indicators of the MPL measurement are as follows.

For the capability variable, the respondents of the poor and the non-poor under the pilot survey viewed dimension of the adequacy is more important than pride and freedom dimensions to establishing the MPL measurement. The proportion of the respondents who considered important the adequacy dimension was 90 percent. Whilst for pride and freedom dimensions, the percentages of importance were only 70 percent and 60 percent respectively. In terms of indicators of these three dimensions of capability variable, eight indicators of the adequacy dimension have higher percentages of importance at 86.7 percent and above, except two indicators of the adequacy dimension which have the percentage of importance at 80 percent each. For indicators of pride dimension, the percentage of importance of protection from harassment indicator was 86.7 percent, while the rest of the two indicators of this dimension was 80 percent each. For the indicators of freedom dimension, two indicators have the percentage of importance at 80 percent each. Only the gender-equal treatment indicator that has a percentage of importance is less than 80 percent (76.7\%). See Table 1.

With respect to dimensions of empowerment variable, the dimensions of public service, and equality of law have the percentage of importance at 80 percent each. While gender equality and the physical limitation dimensions have a percentage of importance at 76.7 


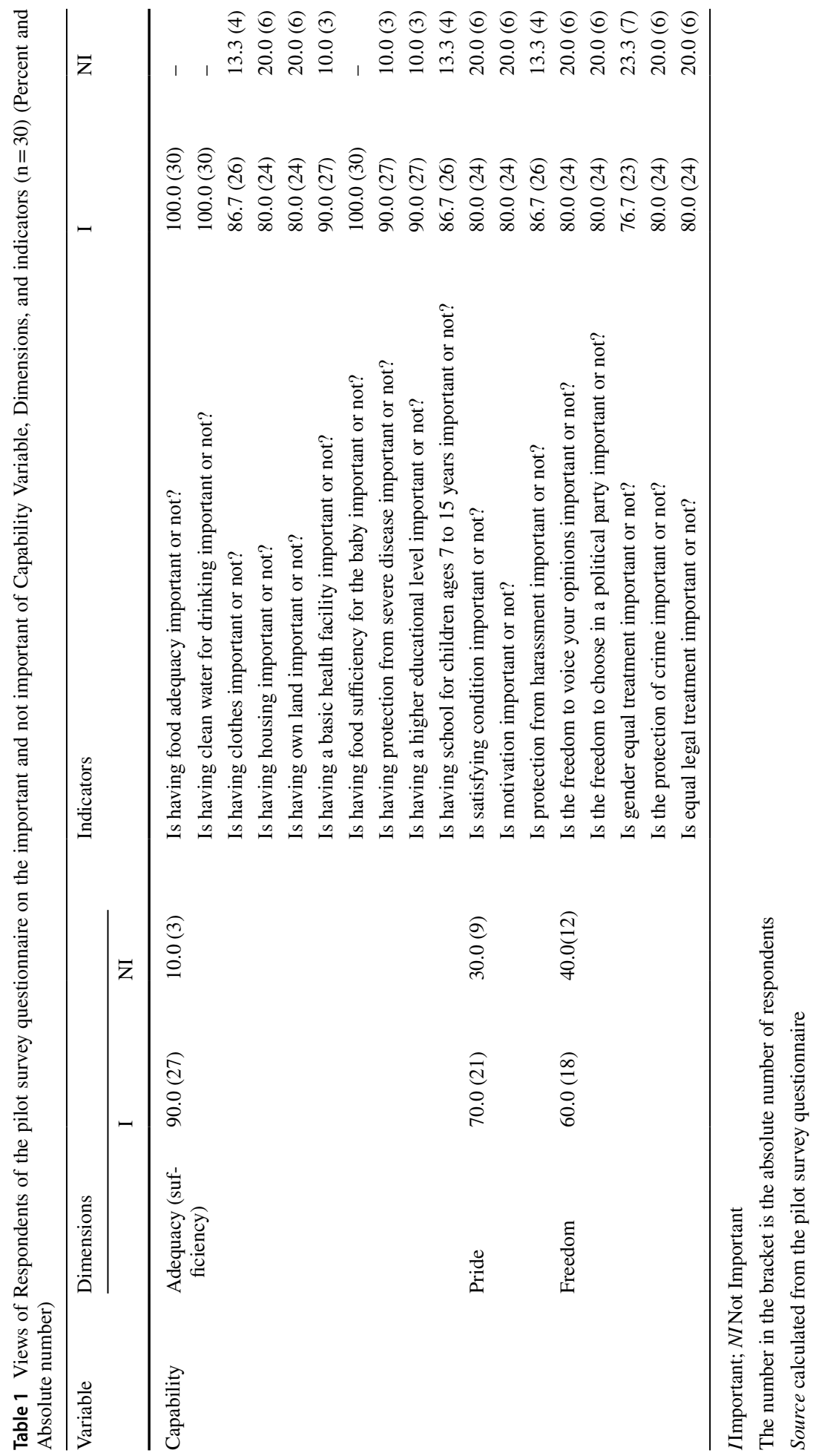




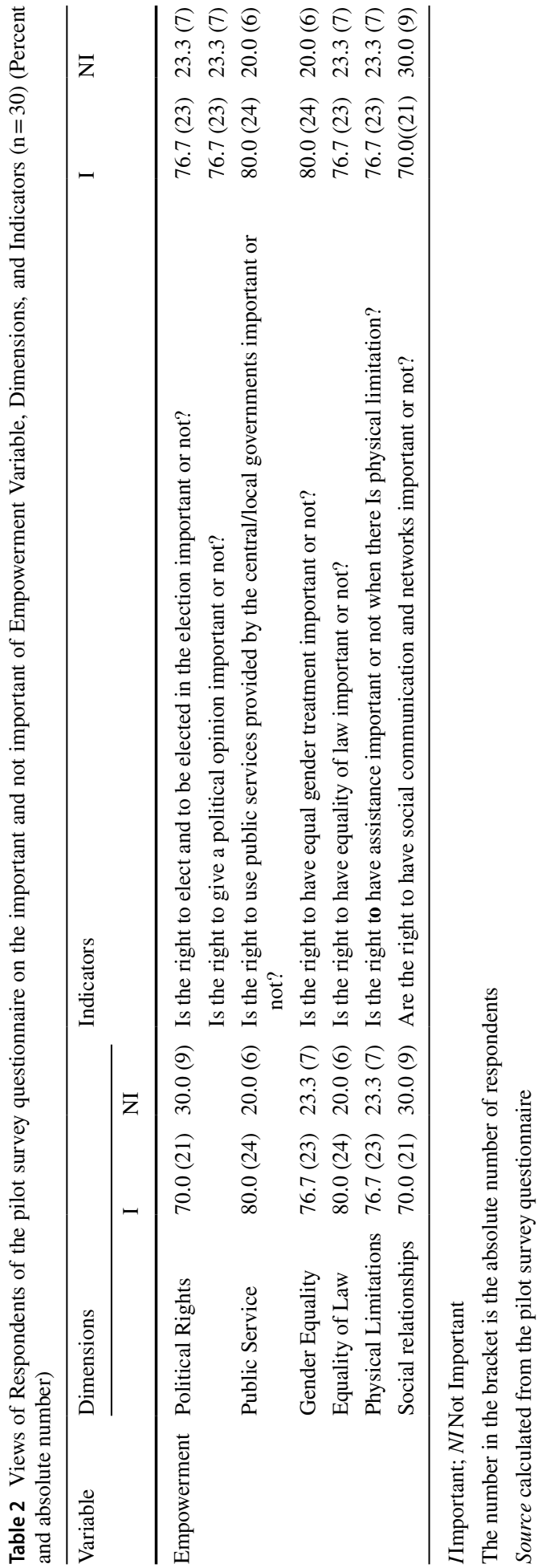


percent each. However, the other two dimensions of political rights and social relations were viewed as important to establishing the MPL measurement only by 70 percent each. As to indicators, the right to have social communication and networks indicator has less important than the other six indicators of empowerment variable (Table 2). These results suggest that all dimensions and indicators of empowerment variable are important to develop the MPL measurement.

Concerning dimensions and indicators of the opportunity variable, the poor and the non-poor household heads respondents under the pilot survey have also no objection. This indicates dimensions and indicators of opportunity variable proposed by the World Bank (2001) are useful for developing the MPL measurement. Detailed of the percentage of importance for each dimension and indicator of this opportunity variable was shown in Table 3.

The results of the pilot survey questionnaire also confirmed the importance of dimensions and indicators of security variable. This security variable has four dimensions and nine indicators. Detailed dimensions and indicators of security variable considered important by the respondents of the pilot for the main survey were given in Table 4. As can be seen in this Table, the proportion of vulnerability of disaster has been viewed as the most important (90 percent), followed by other three dimensions of vulnerability against financial crisis, vulnerability against social conflict, and vulnerability against disease. While for indicators, eight indicators of security variable were viewed as important to be used in the MPL measurement at 80 percent and above. Only the indicator of residential location away from prone to the disaster was viewed as important by 70 percent of respondents under the pilot survey questionnaire.

Judging from the above results, all variables, dimensions, and indicators of capability, empowerment, opportunity, and security proposed by Sen (1999) and the World Bank (2001) were considered important by the urban poor and non-poor household head respondents in the capital city of Jakarta. These variables, dimensions, and indicators were viewed as important by respondents at 70 percent and above. The total number of indicators accepted to be used in developing the MPL measurement is 55 indicators. These are composed of 18 indicators of capability variable, 7 indicators of empowerment variable, 21 indicators of opportunity variable, and 9 indicators of security variable.

\subsection{Results of the Main Survey Questionnaire on Variables, Dimensions, and Indicators to Develop the MPL Measurement and the Importance of the MPL to Replace the Expenditure Poverty Line}

The results of the main survey questionnaire of 589 household head respondents of the poor and the non-poor showed interesting findings. Unlike the results of the pilot survey questionnaire, the main survey questionnaire found that out of four variables, only three variables were viewed as important to establishing the MPL measurement. The proportion of the poor and the non-poor household head respondents who stated the importance of these three variables is 83.1 percent. Whilst the rest of the 16.9 percent of respondents in six survey locations agree to have all four variables in the formulation of MPL measurement (Table 5).

The detailed percentage values of the importance of these four variables are shown in Tables 6, 7, 8, and 9. From these Tables, three variables have higher percentage values of the important greater than 65.0 percent. These three variables are capability (84.6\%), 


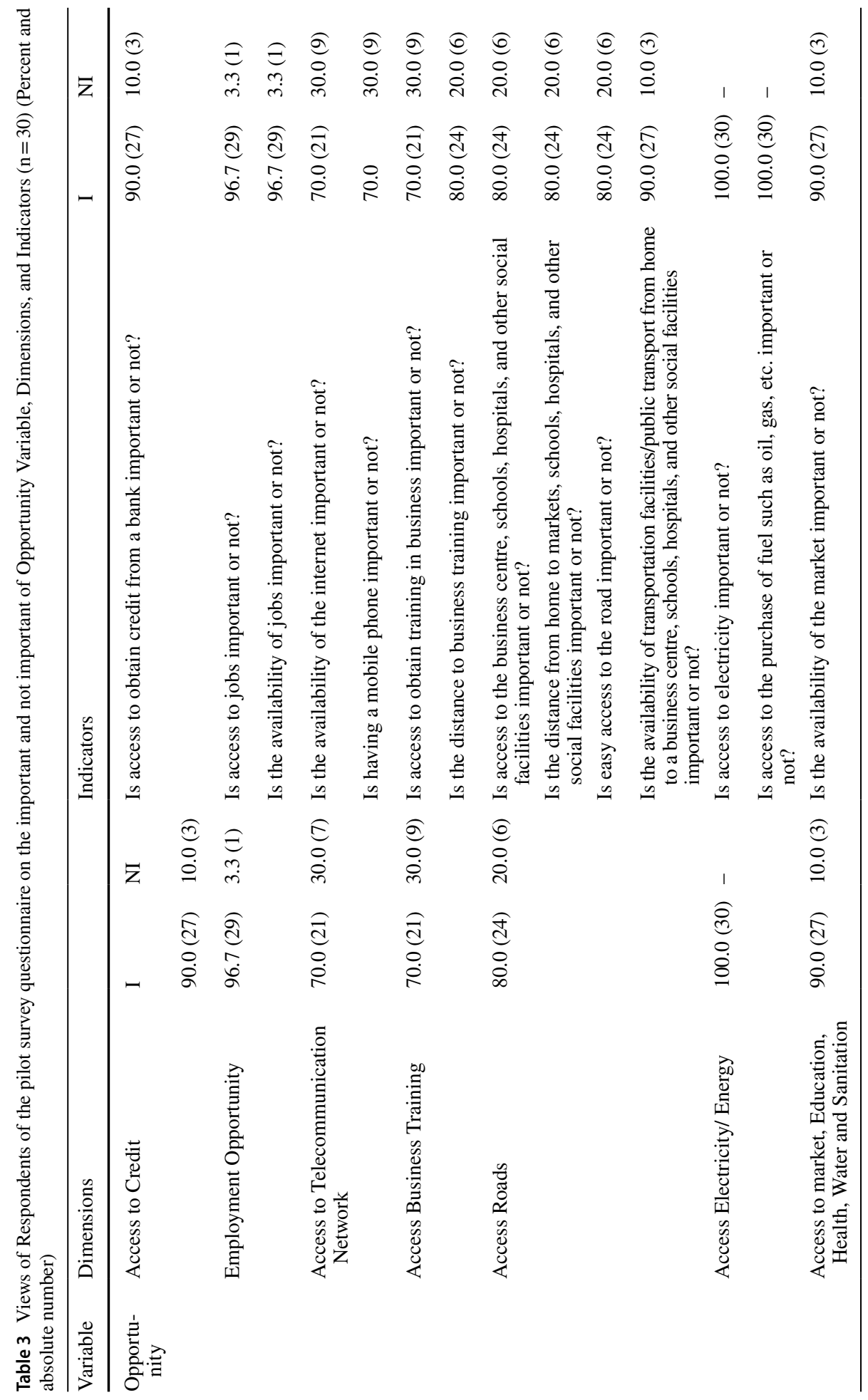




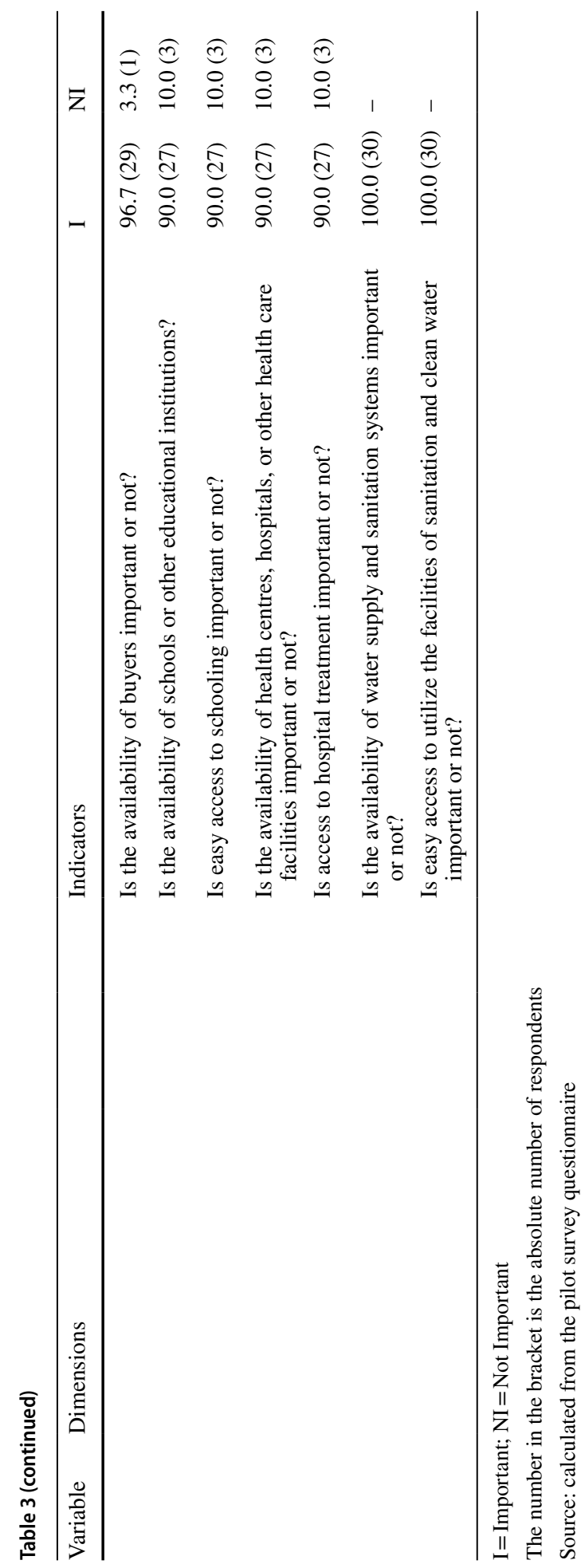




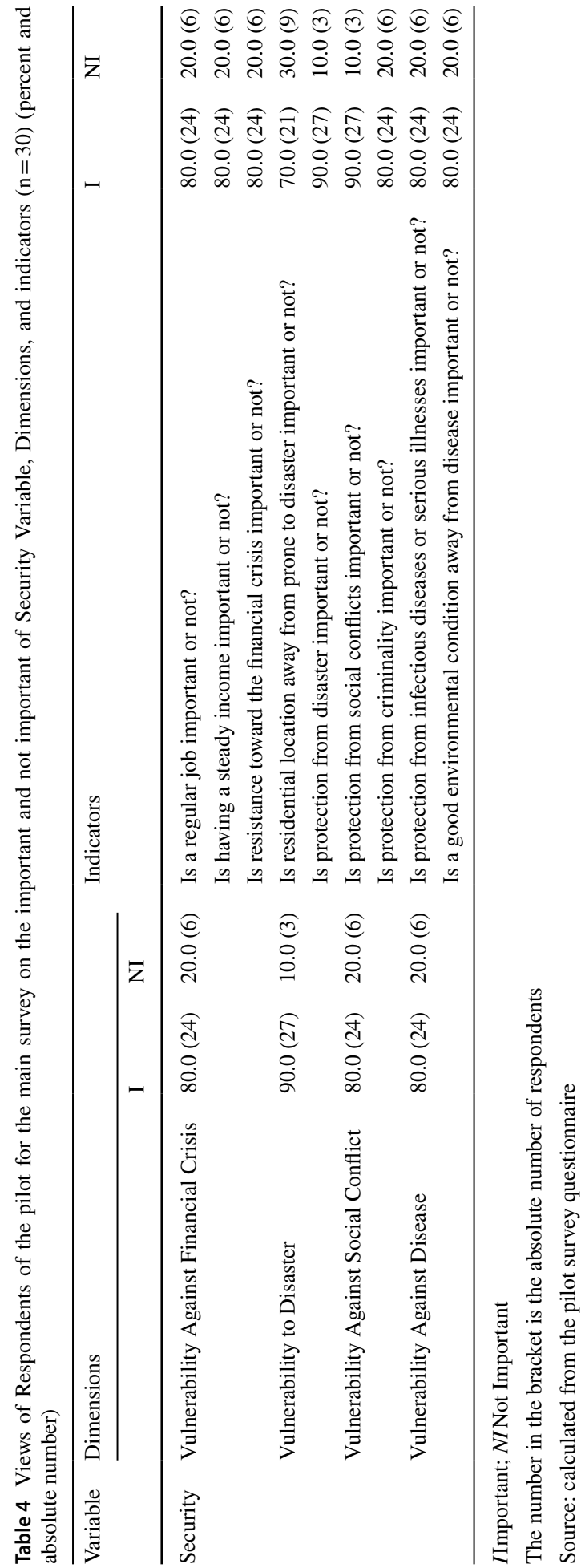




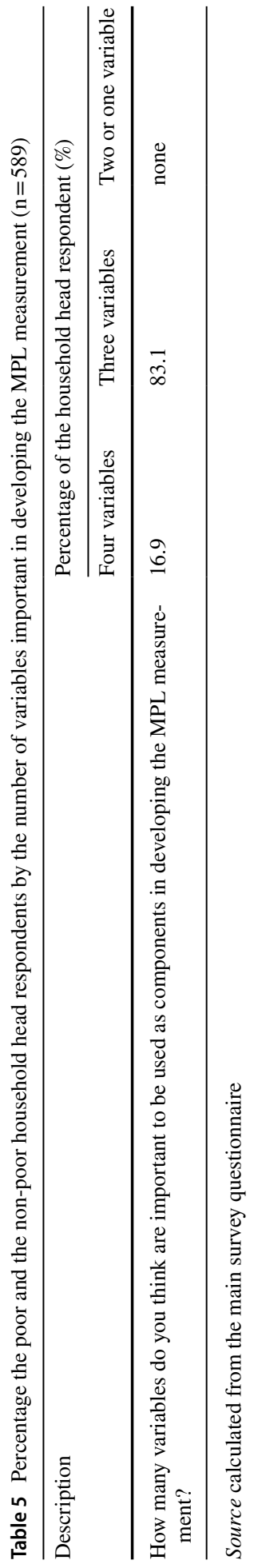




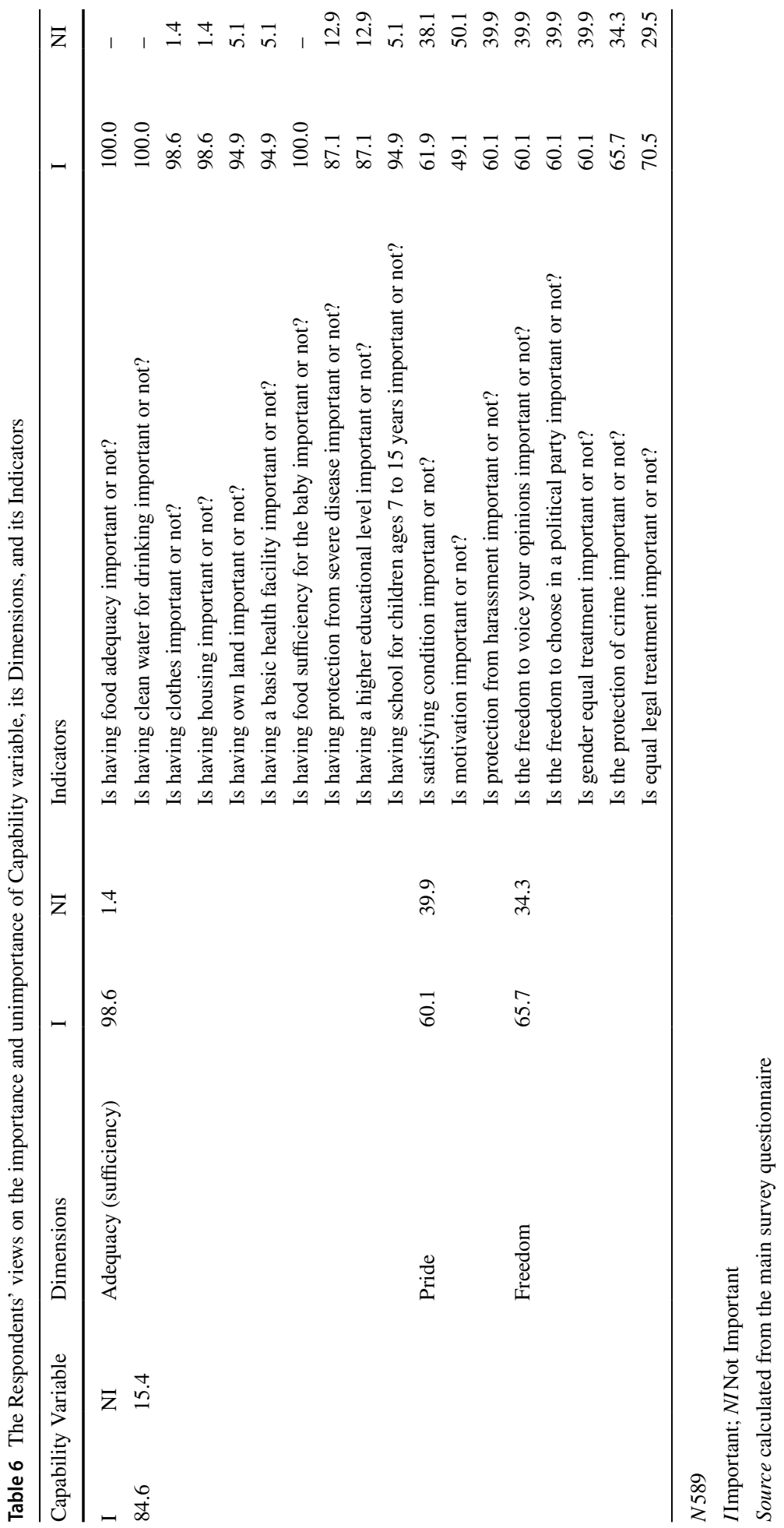




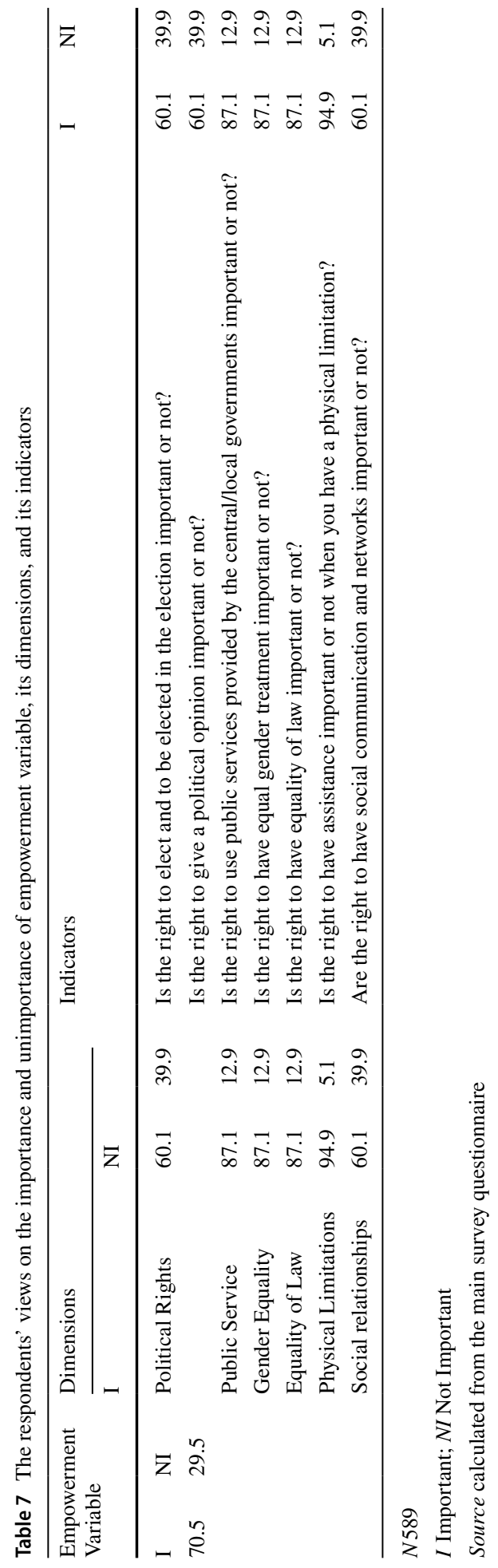




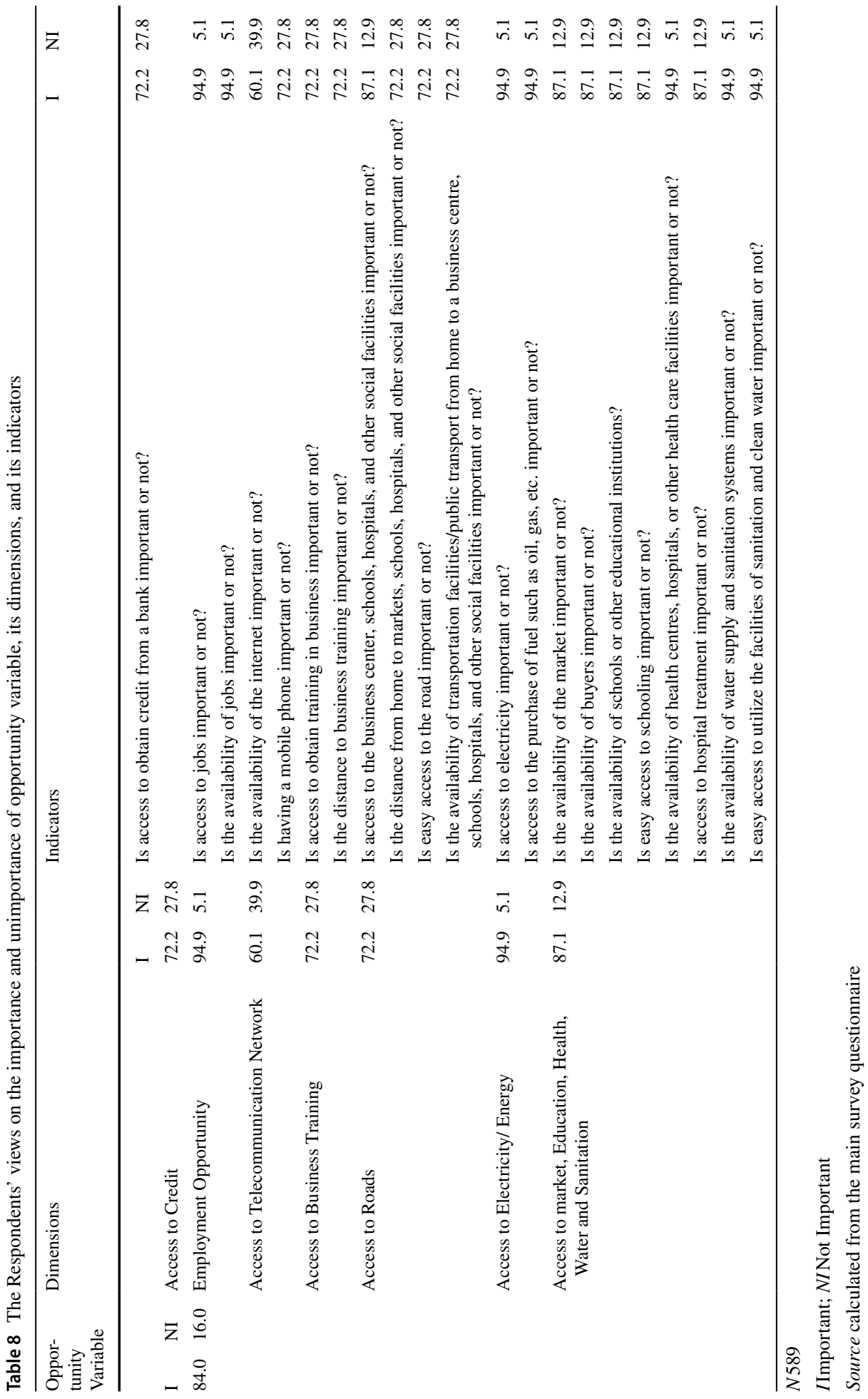




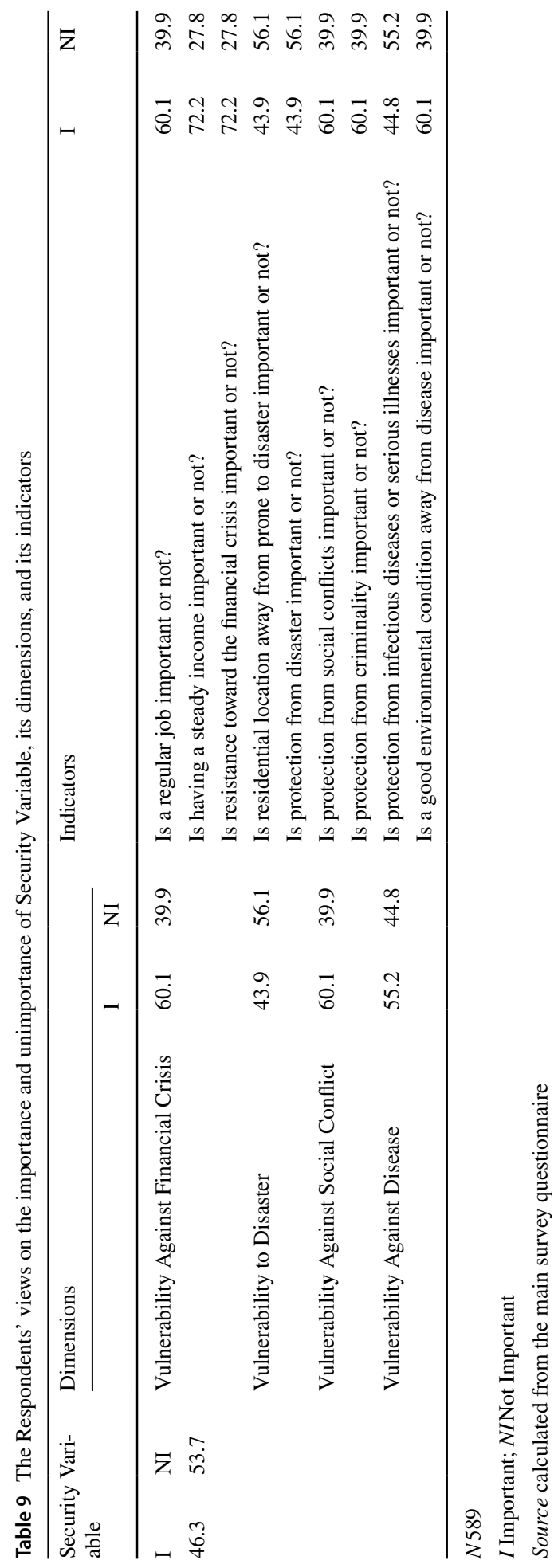


Table 10 The proportion of respondents who viewed the importance and unimportant to replace the income/expenditure poverty with the MPL measurement

Description

Important Not important

What do you think of the MPL to Replace the income/expenditure poverty line? 87.1

12.9

Source calculated from the main survey questionnaire

empowerment (70.5\%), and opportunity (84.0\%) variables, while the percentage of the importance of security variable is only 46.3 percent.

However, in terms of the detailed dimensions and indicators of each variable, the results of the main survey questionnaire are as follows. For dimensions of capability variable, for instance, the dimension of adequacy is viewed as important by 98.6 percent of the respondents, while the percentage of respondents who viewed the importance of the pride and freedom dimensions was 60.1 percent and 65.7 percent respectively. For indicators, all ten indicators of adequacy dimension are viewed as important by the respondents under the main survey. Whereas the importance of indicators of pride and freedom dimensions are viewed between 49.1 percent and 70.5 percent (Table 6).

For dimensions and indicators of empowerment variable, four dimensions of physical limitation, public service, gender equality, and equality of law have been viewed greater importance than dimensions of political rights and social relationship. The percentages of the importance of these four dimensions in developing the MPL measurement are 94.9 percent for the physical limitations dimension and the rest of the three dimensions are at 87.1 percent each. However, the importance of the other two dimensions of political rights and social relationships are 60.1 percent each. For indicators, indicators of the right to have assistance when you have a physical limitation, the right to have equality of law, the right to use public services provided by the central/local governments, and the right to have equal gender treatment are viewed higher important than the rest of the three indicators (see, Table 7).

For dimensions of opportunity variable, the results showed that dimension of access to telecommunication on the network has been viewed less importance at 60.1 percent than dimensions of employment opportunity (94.9 percent), access to electricity/energy (94.9 percent), access to market, education, health, water and sanitation (87.1 percent), access to credit, access to business training, and access to roads at 72.2 percent each. For indicators, the indicator of the availability of the internet is viewed as important only by 60.1 percent of respondents, while the rest of the indicators are viewed as important by more than 70 percent of respondents under survey (Table 8).

For the security variable, the response given by the respondents under the main survey questionnaire is quite surprising. This variable was viewed as important to be used in establishing the MPL measurement only by 46.3 percent of respondents. Of the four dimensions of this variable, two dimensions have been viewed as important by 60.1 percent of respondents. These two dimensions are vulnerability against financial crisis and vulnerability against social conflict. Whereas the other two dimensions of vulnerability against disease and vulnerability to disaster are viewed as important by 55.2 percent and 43.9 percent respondents. Concerning indicators of this variable, two indicators of having a steady income and resistance toward the financial crisis have been viewed as important by 72.2 percent each. Whilst the rest of the indicators are viewed as important by less than 72.2 percent of respondents (Table 9). 
Furthermore, the respondents under the main survey who viewed the importance to replace the use of the present official expenditure poverty line with the MPL measurement was 87.1 percent. Only 12.9 percent considered it is unimportant if the expenditure poverty line was replaced by MPL measurement as the poverty line (Table 10).

\subsection{Results of In-depth Interview on Variables, Dimensions, and Indicators on the MPL Measurement and the Importance of the MPL to Replace the Expenditure Poverty Line}

The responses of interviewees under the survey also confirmed the three variables of capability, empowerment, and opportunity are important in developing the MPL measurement. In terms of indicators, ten indicators of adequacy (sufficiency) dimension of capability variable are viewed as important in the MPL measurement. The reason for this, as said by the heads of village and community members in rural areas of Semarang and Goa (Makassar), was due to the facts of the many lack conditions found in their villages. Access to health facilities and access to schools for children, for instance, are still poor in these rural areas. The village community has to struggle to get access to good public health care. The facility is limited and lacks main medical facilities for proper health care. They are often referred to the state hospital in Semarang City and/or Goa District (South Sulawesi province) for a health examination. They suggest improvement in health care provision in the existing public health services in this place is a must to reduce the incidence of poverty in these rural areas.

Also, access to school for children was not easy and the school facilities were limited. School children have to take transportation to access schools located in the sub-district. The school facility is still limited not only in terms of the number of teachers but also in terms of the library. In addition to that, access to clean water for drinking was limited not only in the rural areas of Semarang, Goa-Makasar, and Surabaya but also in the cities of Padang and Bogor under survey. The poor household heads in these locations have to heavily depend on natural resources with wells, and boreholes. If not, they have to buy portable clean water for drinking from street water merchants. Other situations that made the respondents view indicators of adequacy dimension important were associated with the availability of agricultural land as their main source of income. As pointed out by the heads of the villages interviewed in the rural areas of Semarang and Surabaya:

"Things are difficult these days here as many lands are now owned by people from the city. Because we all do farming for a living, there is pressure on land. This situation has resulted in increased out-migration especially for the youth as they have to seek jobs". Due to this condition, it is no doubt that respondents under the questionnaire survey viewed that 10 indicators of the adequacy dimension of capability variable important in constructing the MPL measurement, and hence we fully agree with their views, said by the heads of the village in rural areas of Semarang and Surabaya.

For other indicators of pride and freedom dimensions of capability variable (e.g. protection of harassments, freedom to choose a political party, and protection of crime), the interviewees in the survey locations agree with the respondents' objections to these dimensions as given in the main survey questionnaire. As the poor household head interviewed in a rural area in Semarang, for instance, said: 
How can we think pride and freedom if we always have difficulties fulfilling our daily food needs. My wife has to work as a housemaid in the city on daily basis just for the sake to help me to earn income.

For the rest of the indicators of empowerment and opportunity variables, the interviewees have different views depending on the survey locations. In the urban areas of DKI Jakarta, Bogor, and Padang, for example, the heads of the village, the community members, and the poor and the non-poor household heads interviewed also have no objections. In other words, they agree with the views pointed out by the respondents in the main survey questionnaire. For an indicator of the political right, for example, poor communities were rarely been given the right to be elected and to give a political opinion, said by the community member the city of Padang. Similarly. for indicators of public service, gender equality, and equality of law dimensions of empowerment variable, these empowerment indicators still needed to be improved. The equality of law is the first dimension of the empowerment variable that needs to be given attention in these cities, followed by public service, and gender equality dimensions.

In rural areas of Semarang, Surabaya, and Goa, however, the interviewees in these locations give more attention particularly to indicators of all dimensions of opportunity variable. The reason is simply because of the phenomenon of the high cost of agricultural inputs (e.g. seeds and fertilizers), market taxes, high medical bills, the strict collateral requirement for credit access, lacks market access, access to jobs, access to energy, and access to health, and water and sanitation are still present in the survey locations. These situations like it or not need to be improved to minimize the poor becoming poorer. Therefore, concerns for these indicators in developing the MPL measurement are also a must.

Based on the above explanations, the interviewees under surveyed agreed the present income/expenditure poverty line need to be expanded by accommodating indicators of capability, empowerment, and opportunity variables. As said by the heads of villages and the community members under survey in Semarang (Central Java province) and Goa, Makassar (South Sulawesi Province) as follows:

The use of multidimensional poverty measurement is very good as our problems here are not limited to food problem only but also the lack our access to employment, school, clean water for drinking, and sanitation, etc. We hope the government helps us to improve our living conditions here

A similar opinion was also pointed out, for instance, by the community member and the poor and the non-poor households interviewed in Surabaya (East Java Province), and in the cities of Padang (West Sumatra province) and Bogor (West Java province) by saying:

It is time for the government to replace the use of income/expenditure poverty measurement with the MPL measurement. By using this multidimensional poverty measurement, the incidence of poverty in this country will no more become a long-standing problem.

\subsection{Hierarchy of Variables in Developing the MPL}

Concerning the hierarchy of variables in developing the MPL, the respondents under the main survey agreed that there should be no hierarchy of importance of the variables in developing the MPL measurement as well as in formulating policy and programs to eradicate the incidence of poverty. The proportion of respondents who viewed it unimportant 
Table 11 Percentage of Respondents on the important and not important of Hierarchy of variables in developing the MPL $(n=589)$

\begin{tabular}{lll}
\hline Description & Important & Not important \\
\hline $\begin{array}{l}\text { Do you think it is important to have a hierarchy of variables in developing the } \\
\text { MPL? }\end{array}$ & 13.1 & 86.9 \\
\hline
\end{tabular}

Source calculated from the main survey questionnaire

to have a hierarchy of variables in developing the MPL measurement was 86.9 percent. Whilst the rest of 13.1 percent viewed the hierarchy of variables in developing the MPL measurement as important (Table 11). Therefore, the establishment of the MPL measurement in Indonesia has to consider the same importance of the three variables of empowerment, capability, and opportunity. No ranking should be given for one variable towards other variables in formulating the MPL measurement in Indonesia.

\section{Discussion, Conclusions, and Implications}

The purpose of this research was to examine variables, dimensions, and indicators proposed by Sen (1999) and the World Bank (2001) that are viewed as important to develop the MPL measurement directly based on subjective perceptions of the poor and the nonpoor household heads in Indonesia. Moreover, it studied the poor and the non-poor household heads opinions on whether or not the present income/expenditure poverty line is necessary to be replaced by the MPL measurement. Also, it examined views of the poor and the non-poor household heads on whether a hierarchy of variables is important in developing the MPL measurement or not.

In the light of the above findings, the discussion, conclusions, and their related implications were extracted as follows.

First, of the four variables proposed by Sen (1999) and the World Bank (2001) in developing the MPL measurement, there were only three variables that were viewed as important to developing the MPL measurement in Indonesia. These three variables were Sen's capability framework, and two variables of empowerment, and opportunity proposed by the World Bank (2001). The security variable proposed by the World Bank (2001) was not viewed as important in developing the MPL measurement. At least there are two reasons to explain these views. First, it is because more than 70 percent of the consumption bundles of the poor are for food items (CBS, 2019). The second is because the poor might assume that the security variable is in the hand of the government's responsibility as outlined in the National Constitution of Indonesia (LIPI, 2011).

Concerning the dimensions of those three variables, the adequacy dimension of Sen's capability variable was viewed as important to be used in developing the MPL measurement. These findings support the previous studies conducted by Budiantoro (2015); Ningrum et al. (2019); Ridwan (2019); Simanjuntak et al. (2019); Tasmilah (2021). Whilst the other two dimensions of pride and freedom were viewed as less important. The reason for this is certainly because the adequacy/sufficiency dimension is still a big matter for the poor in Indonesia (Asrol \& Hafsah Ahmad, 2018; Firdausy, 2016; Galih Pramono \& Waris Marsisno, 2018). These views also indicate that the proposed three dimensions of Sen's capability framework were more important for adequacy/sufficiency dimension than for pride and freedom dimensions in building the MPL measurement in Indonesia. 
Similarly, for dimensions of the empowerment variable, the findings confirmed that there were only four dimensions viewed as important dimensions in developing the MPL measurement in Indonesia. These four dimensions of empowerment are physical limitations, public service, gender equality, and equality of law. This suggests that the poor and the non-poor household heads respondents in these survey locations still face difficulty to have assistance when they have physical limitations, to have access to using public services, and to have equal law treatment, not to mention the right to have equal gender treatment. These findings are also confirmed by the previous studies (see, for instance, Artha \& Dartanto, 2018; Firdausy, 2020; LIPI, 2011; Ningrum et al., 2019; Ridwan, 2019).

The other two dimensions of the empowerment variable, however, were viewed to have less important in developing the MPL measurement. These two dimensions are political rights and social relations. These views suggest that two dimensions of political rights and social relations of empowerment variable proposed by the World Bank (2001) are less important in measuring the MPL in Indonesia. This may be because these two dimensions were not considered as their daily basic needs on one hand, and because of the rapid growth of information Technology Communication (ITC) development in Indonesia. So, these findings give an update to what has been proposed by the World Bank (2001) that dimensions of political rights and social relations of empowerment variable at least for the case in Indonesia are less important as other four dimensions of empowerment variable as discussed above.

For the opportunity variable, there were only six dimensions of this variable viewed as important to be used for the construction of the MPL measurement. These six dimensions were access to credit, employment opportunity, access to business and training, access to roads, access to electricity and energy, and access to market, education, health, water, and sanitation. The acceptance of these six dimensions and their indicators of opportunity variable indicates that the incidence of poverty in Indonesia has a lot to do with structural problems in that the poor have limited access to those six dimensions (Asep Suryahadi et al., 2012; Budi Rajab, 2017; LIPI, 2011). The only dimension viewed as less important was the dimension of access to the telecommunication network. This indeed, as pointed out above, is not surprising as information communication technology (ICT), especially the use of the smartphone has grown rapidly in Indonesia. The number of the population who used smartphones increased from 28.6 percent in 2015 to 63.3 percent in 2019 (Katadata Indonesia, 2020).

As for indicators of the above four variables, the study found that of the 55 indicators of the MPL measurement, only 35 indicators are viewed as important to develop the MPL measurement in Indonesia. This is composed of ten indicators of adequacy dimension of capability variable, four indicators of four dimensions of empowerment variable, and twenty-one of indicators of opportunity variable. This finding supported the views advanced by Asep Suryahadi et al. (2021); ADB (2014); Sen (1999); and the World Bank (2001) among others that money indicator is necessary but not a sufficient measure in estimating the incidence of poverty as it does not provide a complete picture of well-being for either individuals or households.

Second, concerning the replacement of the present official expenditure poverty line to the MPL measurement, the study found that almost all of the respondents and interviewees under the main survey have no objections. The reason for this argument was because they found ten indicators of adequacy dimension of capability variable, indicators of four dimensions of empowerment variable, and indicators of six dimensions of opportunity variable in their locations were far than they expected. So that by replacing the income/ expenditure poverty line with the MPL measurement, the poverty incidence in their 
locations is expected to change. Moreover, it is because of the present income/expenditure poverty line of Rp. 458,947 per capita/month (or roughly at US\$ 31/capita/month) was considered not realistic to cover their per capita monthly basic needs. This finding supports the previous empirical studies (see, for instance, Artha \& Dartanto, 2018; Firdausy, 2016; LIPI, 2011; Ningrum et al., 2019; Ridwan, 2019; Tasmilah, 2021).

Third, it was pointed out by the respondents and interviewees under the main survey that there should not be any hierarchy of variables in developing the MPL measurement. This suggests that the three variables of opportunity, capability, and empowerment are complementary and they have a relationship between one and another. A capability variable, for instance, was argued to have a close link with the opportunity and empowerment variables. Similarly, the opportunity variable has a relationship with empowerment and capability variables, etc. Thus, these three variables have the same level of importance in the construction of the MPL in estimating the incidence of poverty in Indonesia as well as for strategy, policy, and programs to alleviate the incidence of poverty. This argument is consistent with the statement made by the World Bank in the World Development Report 2000 as follows.

'There is no hierarchy of importance. The elements are deeply complementary. Each part of the strategy affects the underlying causes of poverty addressed by others.'

In conclusion, the study contributes to confirming the present use of unidimensional income/expenditure poverty measurement is an imperfect way to measure the number of the poor in Indonesia as it does not reflect the true living standards of the poor. The MPL measurement is considered a better and reliable method in estimating the incidence of poverty in Indonesia. Three variables, eleven dimensions, and thirty-five indicators are considered important in developing the MPL measurement in Indonesia. There should be no hierarchy of importance of those variables, dimensions, and indicators in developing and measuring the MPL as well as in formulating policy and programs to eradicate the incidence of poverty in Indonesia.

The implications of this study at least are three. First, thirty-five indicators of the three variables of capability, empowerment, and opportunity of the MPL measurement need to be considered in the formulation of future strategies, policies, and programs to alleviate the incidence of poverty in Indonesia. Second, the MPL measurement needs to be employed in estimating the incidence of poverty. Third, the MPL measurement needs to be used in assessing the success or failure of the implementation of strategies, policies, and programs to alleviate the incidence of poverty in Indonesia. However, further studies to more qualify the present perceptions of the poor and the non-poor household heads on the MPL measurement based on a large number of respondents on one hand, and quantify indicators in money terms to develop the MPL, on the other hand, should be done by the government, especially by the CBS and the Ministry of National Planning as they have better resources to do this in Indonesia. 


\section{Appendix 1 Questions Discussed in the FGD Forum}

\section{List of main questions, Resource Persons and Participants of FGD Forum}

List of FGD's participants

Invited Resource Persons:

1. Professor of Sociology, Faculty of Sociology, University of Indonesia.

2. Senior Statistician, Central Board of Statistics

3. Director, SMERU Research Institute

4. Director, the Ministry of National Planning
Other Participants of the FGD Forum
List of Main Questions for Discussion

a. This study aimed to examine variables, dimensions, and indicators of importance to develop the MPL measurement in Indonesia. What are your views or opinions on the importance and the objective of this study? Please explain.

b. What is the unit analysis and the instruments need to be employed for the study? Please explain.

c. What variables, dimensions, and indicators can be used to develop the MPL measurement in Indonesia.

d. Please give your views and opinions on whether or not variables, dimensions, and indicators of the Multidimensional Poverty line measurement proposed by Sen (1999) and The Word Bank (2001) relevant to be used in measuring the MPL in Indonesia?

e. What variables, dimensions, and indicators to develop the MPL measurement can be used as materials for the survey instruments

a. 9 Researchers of Centre for Economic Research-Indonesian Institute of Sciences.

b. 6 Researchers from the Centre of population and Manpower StudiesIndonesian Institute of Sciences

c. 1 research associate from the Central Board of Statistics

d. 2. Lecturers of Tri-dharma Widya Economic and Business College

e. 1 Researcher of Institute for Development Economics and Finance (INDEF)

f. 2 Representatives of the poor community in Jakarta 


\section{Appendix 2 Questionnaire of Pilot for the main survey}

A. Please state yourself as a poor or non-poor household head.

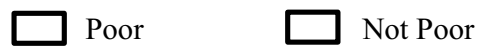

B. Please tick (V) the answer that you think is important or not important for each question in the following box

- Capability Variable, Dimensions, and Indicators.

\begin{tabular}{|c|c|c|c|c|}
\hline Variable & Dimensions & Indicators & $\begin{array}{l}\text { Impor- } \\
\text { tant }\end{array}$ & Not important \\
\hline \multirow[t]{18}{*}{ Capability $(\ldots .)}$. & \multirow{10}{*}{$\begin{array}{l}\text { Adequacy } \\
\text { (sufficiency) } \\
(\ldots .)\end{array}$} & $\begin{array}{l}\text { Is having food adequacy important or } \\
\text { not? }\end{array}$ & & \\
\hline & & $\begin{array}{l}\text { Is having clean water for drinking } \\
\text { important or not? }\end{array}$ & & \\
\hline & & Is having clothes important or not? & & \\
\hline & & Is having housing important or not? & & \\
\hline & & Is having own land important or not? & & \\
\hline & & $\begin{array}{l}\text { Is having a basic health facility impor- } \\
\text { tant or not? }\end{array}$ & & \\
\hline & & $\begin{array}{l}\text { Is having food sufficiency for the baby } \\
\text { important or not? }\end{array}$ & & \\
\hline & & $\begin{array}{l}\text { Is having protection from severe disease } \\
\text { important or not? }\end{array}$ & & \\
\hline & & $\begin{array}{l}\text { Is having a higher educational level } \\
\text { important or not? }\end{array}$ & & \\
\hline & & $\begin{array}{l}\text { Is having school for children ages } 7 \text { to } \\
15 \text { years important or not? }\end{array}$ & & \\
\hline & \multirow[t]{3}{*}{ Pride $(\ldots \ldots)$} & $\begin{array}{l}\text { Is satisfying condition important or } \\
\text { not? }\end{array}$ & & \\
\hline & & Is motivation important or not? & & \\
\hline & & $\begin{array}{l}\text { Is protection from harassment impor- } \\
\text { tant or not? }\end{array}$ & & \\
\hline & \multirow[t]{5}{*}{ Freedom $(\ldots .)}$. & $\begin{array}{l}\text { Is the freedom to voice your opinions } \\
\text { important or not? }\end{array}$ & & \\
\hline & & $\begin{array}{l}\text { Is the freedom to choose in a political } \\
\text { party important or not? }\end{array}$ & & \\
\hline & & $\begin{array}{l}\text { Is gender equal treatment important } \\
\text { or not? }\end{array}$ & & \\
\hline & & $\begin{array}{l}\text { Is the protection of crime important } \\
\text { or not? }\end{array}$ & & \\
\hline & & $\begin{array}{l}\text { Is equal legal treatment important or } \\
\text { not? }\end{array}$ & & \\
\hline
\end{tabular}


- Empowerment Variable, Dimensions, and Indicators.

\begin{tabular}{|c|c|c|c|c|}
\hline Variable & Dimensions & Indicators & $\begin{array}{l}\text { Impor- } \\
\text { tant }\end{array}$ & Not important \\
\hline \multirow[t]{7}{*}{ Empowerment (.....) } & Political Rights (...) & $\begin{array}{l}\text { Is the right to elect and } \\
\text { to be elected in the } \\
\text { election important } \\
\text { or not? }\end{array}$ & & \\
\hline & & $\begin{array}{l}\text { Is the right to give a } \\
\text { political opinion } \\
\text { important or not? }\end{array}$ & & \\
\hline & Public Service (....) & $\begin{array}{l}\text { Is the right to use public } \\
\text { services provided by } \\
\text { the central/local gov- } \\
\text { ernments important } \\
\text { or not? }\end{array}$ & & \\
\hline & Gender Equality (...) & $\begin{array}{l}\text { Is the right to have equal } \\
\text { gender treatment } \\
\text { important or not? }\end{array}$ & & \\
\hline & Equality of Law (...) & $\begin{array}{l}\text { Is the right to have } \\
\text { equality of law impor- } \\
\text { tant or not? }\end{array}$ & & \\
\hline & $\begin{array}{l}\text { Physical Limitations } \\
\quad(\ldots .)\end{array}$ & $\begin{array}{l}\text { Is the right to have assis- } \\
\text { tance important or not } \\
\text { when there Is physical } \\
\text { limitation? }\end{array}$ & & \\
\hline & $\begin{array}{l}\text { Social relationships } \\
\quad(\ldots .)\end{array}$ & $\begin{array}{l}\text { Are the right to have } \\
\text { social communication } \\
\text { and networks impor- } \\
\text { tant or not? }\end{array}$ & & \\
\hline
\end{tabular}

- Opportunity Variable, Dimensions, and Indicators. 


\begin{tabular}{|c|c|c|c|c|}
\hline Variable & Dimensions & Indicators & Important & Not Important \\
\hline \multirow[t]{21}{*}{ Opportunity $(\ldots .)}$. & Access to Credit (...) & $\begin{array}{l}\text { Is access to obtain credit from a } \\
\text { bank important or not? }\end{array}$ & & \\
\hline & $\begin{array}{l}\text { Employment Opportunity } \\
(\ldots . .)\end{array}$ & $\begin{array}{l}\text { Is access to jobs important or } \\
\text { not? }\end{array}$ & & \\
\hline & & $\begin{array}{l}\text { Is the availability of jobs impor- } \\
\text { tant or not? }\end{array}$ & & \\
\hline & $\begin{array}{l}\text { Access to Telecommunica- } \\
\text { tion Network }(\ldots . .)\end{array}$ & $\begin{array}{l}\text { Is the availability of the internet } \\
\text { important or not? }\end{array}$ & & \\
\hline & & $\begin{array}{l}\text { Is having a mobile phone impor- } \\
\text { tant or not? }\end{array}$ & & \\
\hline & $\begin{array}{l}\text { Access Business Training } \\
\quad(\ldots .)\end{array}$ & $\begin{array}{l}\text { Is access to obtain training in } \\
\text { business important or not? }\end{array}$ & & \\
\hline & & $\begin{array}{l}\text { Is the distance to business train- } \\
\text { ing important or not? }\end{array}$ & & \\
\hline & Access Roads (...) & $\begin{array}{l}\text { Is access to the business center, } \\
\text { schools, hospitals, and other } \\
\text { social facilities important or } \\
\text { not? }\end{array}$ & & \\
\hline & & $\begin{array}{l}\text { Is the distance from home to } \\
\text { markets, schools, hospitals, and } \\
\text { other social facilities important } \\
\text { or not? }\end{array}$ & & \\
\hline & & $\begin{array}{l}\text { Is easy access to the road impor- } \\
\text { tant or not? }\end{array}$ & & \\
\hline & & $\begin{array}{l}\text { Is the availability of transporta- } \\
\text { tion facilities/public transport } \\
\text { from home to a business center, } \\
\text { schools, hospitals, and other } \\
\text { social facilities important or } \\
\text { not? }\end{array}$ & & \\
\hline & $\begin{array}{l}\text { Access Electricity/ Energy } \\
(\ldots . .)\end{array}$ & $\begin{array}{l}\text { Is access to electricity important } \\
\text { or not? }\end{array}$ & & \\
\hline & & $\begin{array}{l}\text { Is access to the purchase of fuel } \\
\text { such as oil, gas, etc. important } \\
\text { or not? }\end{array}$ & & \\
\hline & $\begin{array}{l}\text { Access to market, Educa- } \\
\text { tion, Health, Water, and }\end{array}$ & $\begin{array}{l}\text { Is the availability of the market } \\
\text { important or not? }\end{array}$ & & \\
\hline & Sanitation $(\ldots .)$. & $\begin{array}{l}\text { Is the availability of buyers } \\
\text { important or not? }\end{array}$ & & \\
\hline & & $\begin{array}{l}\text { Is the availability of schools or } \\
\text { other educational institutions? }\end{array}$ & & \\
\hline & & $\begin{array}{l}\text { Is easy access to schooling } \\
\text { important or not? }\end{array}$ & & \\
\hline & & $\begin{array}{l}\text { Is the availability of health cent- } \\
\text { ers, hospitals, or other health } \\
\text { care facilities important or not? }\end{array}$ & & \\
\hline & & $\begin{array}{l}\text { Is access to hospital treatment } \\
\text { important or not? }\end{array}$ & & \\
\hline & & $\begin{array}{l}\text { Is the availability of water supply } \\
\text { and sanitation systems impor- } \\
\text { tant or not? }\end{array}$ & & \\
\hline & & $\begin{array}{l}\text { Is easy access to utilize the } \\
\text { facilities of sanitation and clean } \\
\text { water important or not? }\end{array}$ & & \\
\hline
\end{tabular}


- Security Variable, Dimensions, and Indicators.

\begin{tabular}{|c|c|c|c|c|}
\hline Variable & Dimensions & Indicators & Important & Not Important \\
\hline \multirow[t]{9}{*}{ Security $(\ldots .)}$. & \multirow{3}{*}{$\begin{array}{l}\text { Vulnerability } \\
\text { Against Financial } \\
\text { Crisis }(\ldots .)\end{array}$} & $\begin{array}{l}\text { Is a regular job } \\
\text { important or not? }\end{array}$ & & \\
\hline & & $\begin{array}{l}\text { Is having a steady } \\
\text { income important } \\
\text { or not? }\end{array}$ & & \\
\hline & & $\begin{array}{l}\text { Is resistance toward } \\
\text { the financial } \\
\text { crisis important } \\
\text { or not? }\end{array}$ & & \\
\hline & \multirow[t]{2}{*}{$\begin{array}{c}\text { Vulnerability to } \\
\text { Disaster }(\ldots . .)\end{array}$} & $\begin{array}{l}\text { Is residential loca- } \\
\text { tion away from } \\
\text { prone to disaster } \\
\text { important or not? }\end{array}$ & & \\
\hline & & $\begin{array}{l}\text { Is protection from } \\
\text { disaster impor- } \\
\text { tant or not? }\end{array}$ & & \\
\hline & \multirow[t]{2}{*}{$\begin{array}{l}\text { Vulnerability } \\
\text { Against Social } \\
\text { Conflict (...) }\end{array}$} & $\begin{array}{l}\text { Is protection from } \\
\text { social conflicts } \\
\text { important or not? }\end{array}$ & & \\
\hline & & $\begin{array}{l}\text { Is protection from } \\
\text { criminality } \\
\text { important or not? }\end{array}$ & & \\
\hline & \multirow[t]{2}{*}{$\begin{array}{l}\text { Vulnerability } \\
\text { Against Disease } \\
(\ldots .)\end{array}$} & $\begin{array}{l}\text { Is protection from } \\
\text { infectious dis- } \\
\text { eases or serious } \\
\text { illnesses impor- } \\
\text { tant or not? }\end{array}$ & & \\
\hline & & $\begin{array}{l}\text { Is a good environ- } \\
\text { mental condition } \\
\text { away from } \\
\text { disease important } \\
\text { or not? }\end{array}$ & & \\
\hline
\end{tabular}

C. After answering all questions in this questionnaire, please state your comments whether or not you have any difficulties in:
a. reading it
b. understanding it
c. no problem

D. Please state how many minutes you complete this questionnaire?
a. Less than 15 minutes
b. 15-20 minutes
c. 20-25 minutes
d. More than 25 minutes 


\section{Appendix 3 Main Survey Questionnaire}

\section{Main Survey Questionnaire}

A. Screening Questions.

(Please state yourself as a Poor or Non-Poor Household head

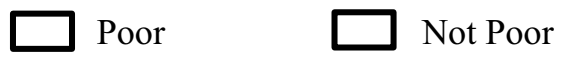

B. Respondents' Identity (Please tick (V) your answer).

Sex :

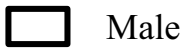

$\square$ Female

Age :

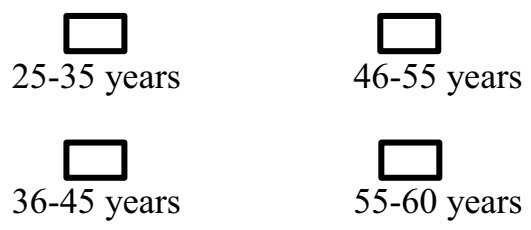

Educational

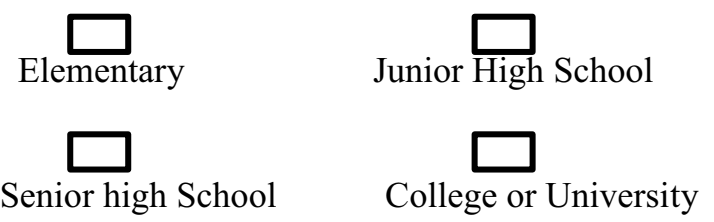

C. How many variables do you think are important to be used as components in developing the MPL measurement?
a. Two or one variable.
b. Three Variables.
c. Four Variables.
d. Don't know.

D. Please tick (V) each of the following boxes the answer that you think is important or not important.

- Capability Variable, Dimensions, and indicators. 


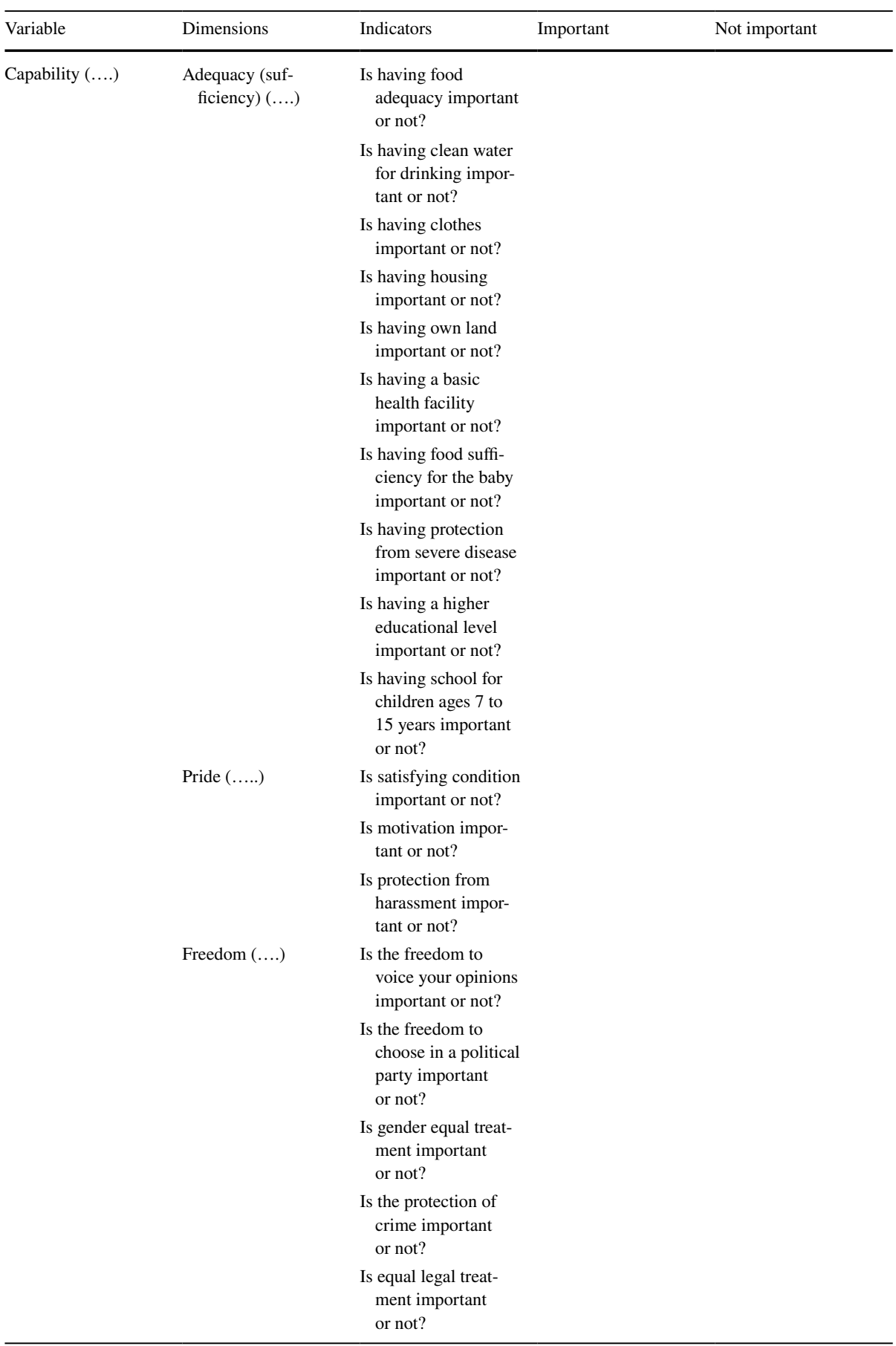


E. Do you think of 10 indicators of adequacy dimension above in developing the MPL measurement are important or not?

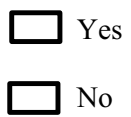

F. Please tick (V) each of the following boxes the answer that you think is important or not important.

- Empowerment Variable, Dimensions, and Indicators.

\begin{tabular}{|c|c|c|c|c|}
\hline Variable & Dimensions & Indicators & Important & Not important \\
\hline \multirow[t]{6}{*}{ Empowerment $(\ldots .)}$. & Political Rights (....) & $\begin{array}{l}\text { Is the right to elect } \\
\text { and to be elected in } \\
\text { the election impor- } \\
\text { tant or not? } \\
\text { Is the right to give a } \\
\text { political opinion } \\
\text { important or not? }\end{array}$ & & \\
\hline & Public Service (....) & $\begin{array}{l}\text { Is the right to use } \\
\text { public services } \\
\text { provided by the } \\
\text { central/local gov- } \\
\text { ernments important } \\
\text { or not? }\end{array}$ & & \\
\hline & Gender Equality (...) & $\begin{array}{l}\text { Is the right to have } \\
\text { equal gender treat- } \\
\text { ment important } \\
\text { or not? }\end{array}$ & & \\
\hline & Equality of Law (....) & $\begin{array}{l}\text { Is the right to have } \\
\text { equality of law } \\
\text { important or not? }\end{array}$ & & \\
\hline & $\begin{array}{l}\text { Physical Limitations } \\
\quad(\ldots .)\end{array}$ & $\begin{array}{l}\text { Is the right to have } \\
\text { assistance impor- } \\
\text { tant or not when } \\
\text { there Is physical } \\
\text { limitation? }\end{array}$ & & \\
\hline & $\begin{array}{l}\text { Social relationships } \\
\quad(\ldots .)\end{array}$ & $\begin{array}{l}\text { Are the right to have } \\
\text { social communica- } \\
\text { tion and networks } \\
\text { important or not? }\end{array}$ & & \\
\hline
\end{tabular}

G. How many dimensions of the empowerment variable do you think are important in developing the MPL measurement?
a. Six dimensions.
b. Five dimensions.
c. Four Dimensions.
d. Less than four dimensions.
e. Don't know. 


\section{H. Please tick (V) each of the following boxes the answer that you think is important or not important.}

- Opportunity Variable, Dimensions, and Indicators.

\begin{tabular}{|c|c|c|c|c|}
\hline Variable & Dimensions & Indicators & Important & Not Important \\
\hline \multirow[t]{21}{*}{ Opportunity $(\ldots)}$. & Access to Credit $(\ldots)$. & $\begin{array}{l}\text { Is access to obtain credit from a bank } \\
\text { important or not? }\end{array}$ & & \\
\hline & Employment Oppor- & Is access to jobs important or not? & & \\
\hline & tunity $(\ldots .)$. & $\begin{array}{l}\text { Is the availability of jobs important } \\
\text { or not? }\end{array}$ & & \\
\hline & $\begin{array}{l}\text { Access to Telecom- } \\
\text { munication Net- }\end{array}$ & $\begin{array}{l}\text { Is the availability of the internet } \\
\text { important or not? }\end{array}$ & & \\
\hline & work $(\ldots .)$. & $\begin{array}{l}\text { Is having a mobile phone important } \\
\text { or not? }\end{array}$ & & \\
\hline & $\begin{array}{c}\text { Access Business } \\
\text { Training }(\ldots . .)\end{array}$ & $\begin{array}{l}\text { Is access to obtain training in business } \\
\text { important or not? }\end{array}$ & & \\
\hline & & $\begin{array}{l}\text { Is the distance to business training } \\
\text { important or not? }\end{array}$ & & \\
\hline & Access Roads (....) & $\begin{array}{l}\text { Is access to the business center, } \\
\text { schools, hospitals, and other social } \\
\text { facilities important or not? }\end{array}$ & & \\
\hline & & $\begin{array}{l}\text { Is the distance from home to markets, } \\
\text { schools, hospitals, and other social } \\
\text { facilities important or not? }\end{array}$ & & \\
\hline & & $\begin{array}{l}\text { Is easy access to the road important } \\
\text { or not? }\end{array}$ & & \\
\hline & & $\begin{array}{l}\text { Is the availability of transportation } \\
\text { facilities/public transport from } \\
\text { home to a business center, schools, } \\
\text { hospitals, and other social facilities } \\
\text { important or not? }\end{array}$ & & \\
\hline & $\begin{array}{l}\text { Access Electricity/ } \\
\text { Energy }(\ldots . .)\end{array}$ & $\begin{array}{l}\text { Is access to electricity important or } \\
\text { not? }\end{array}$ & & \\
\hline & & $\begin{array}{l}\text { Is access to the purchase of fuel such } \\
\text { as oil, gas, etc. important or not? }\end{array}$ & & \\
\hline & & $\begin{array}{l}\text { Is the availability of the market } \\
\text { important or not? }\end{array}$ & & \\
\hline & & $\begin{array}{l}\text { Is the availability of buyers important } \\
\text { or not? }\end{array}$ & & \\
\hline & & $\begin{array}{l}\text { Is the availability of schools or other } \\
\text { educational institutions? }\end{array}$ & & \\
\hline & & $\begin{array}{l}\text { Is easy access to schooling important } \\
\text { or not? }\end{array}$ & & \\
\hline & & $\begin{array}{l}\text { Is the availability of health centers, } \\
\text { hospitals, or other health care facili- } \\
\text { ties important or not? }\end{array}$ & & \\
\hline & & $\begin{array}{l}\text { Is access to hospital treatment impor- } \\
\text { tant or not? }\end{array}$ & & \\
\hline & & $\begin{array}{l}\text { Is the availability of water supply and } \\
\text { sanitation systems important or not? }\end{array}$ & & \\
\hline & & $\begin{array}{l}\text { Is easy access to utilize the facilities } \\
\text { of sanitation and clean water impor- } \\
\text { tant or not? }\end{array}$ & & \\
\hline
\end{tabular}


I. Do you think the six dimensions and their indicators of the opportunity variable in developing the MPL measurement are important or not?

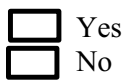

J. Please tick (V) each of the following boxes the answer that you think is important or not in establishing the MPL.

Security Variable, Dimensions, and Indicators.

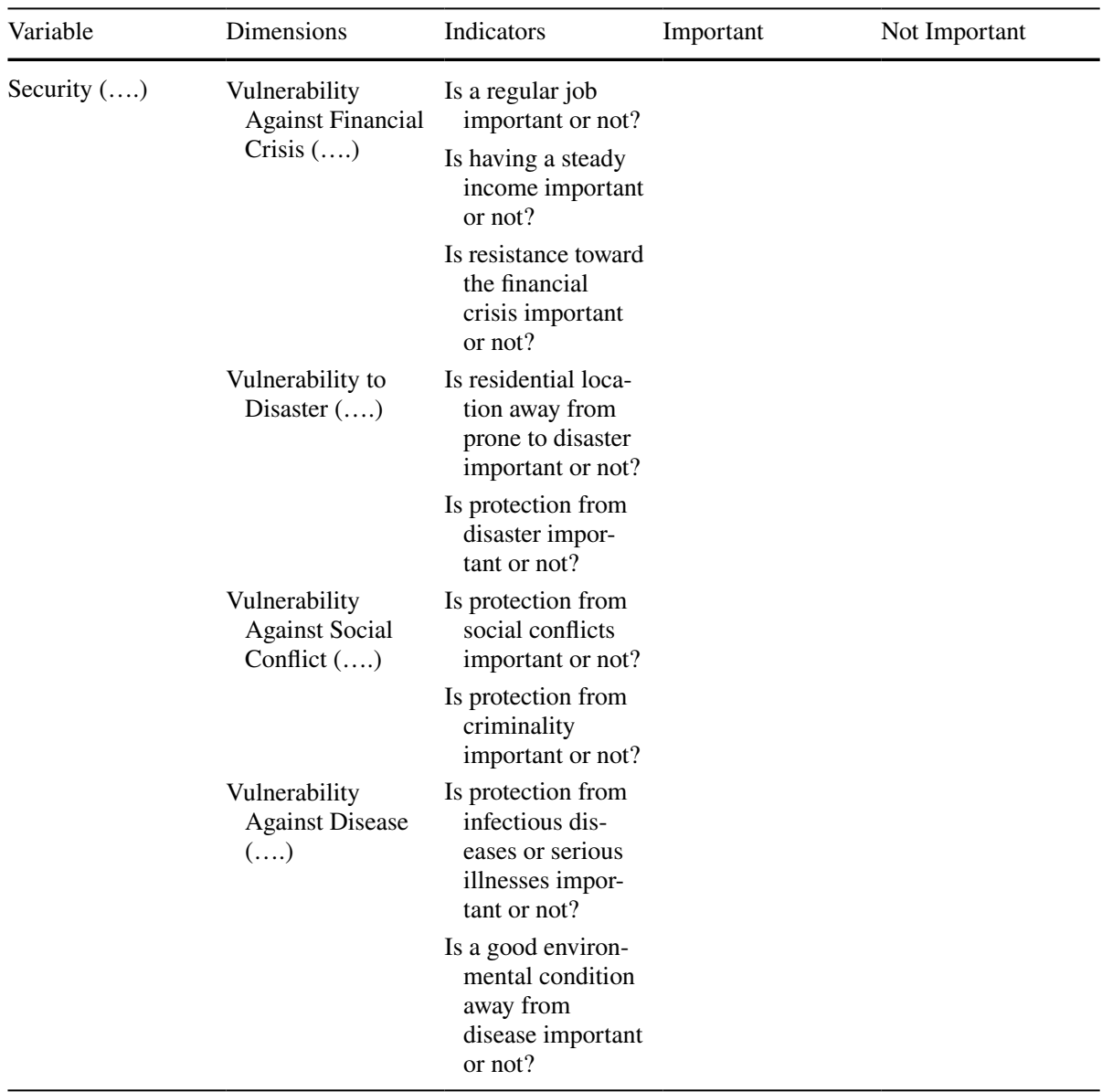


K. Do you think the income/expenditure poverty line needs to be replaced by this MPL measurement or not?

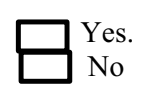

XII. Do you think it is important or not to have a hierarchy of variables in developing the MPL measurement?

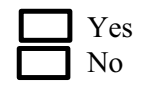

\section{Appendix 4 In-depth Interviews materials for Interviewees in the survey locations}

\section{List of Questions asked in In-depth Interview to Interviewees}

List of Interviewees List of Questions asked to the interviewees

1. The Head of the Village in each survey location

2. Three community members in each survey location

3. Two or three of the poor household heads in each survey location.

4. Two or three of the non-poor household heads in each survey location
1. Do you think Capability, Empowerment, Opportunity, and Security variables are important or not important to measure the Multidimensional Poverty line?

2. Do you have views on other variables or components that need to be added?

3. Do you agree with the views of household heads given in the questionnaire that Capability, Empowerment, Opportunity, and Security variables are important or not important to measure the Multidimensional Poverty line?

4. Do you agree that security is not important to measure poverty in this place and why? Please explain.

5. Do you agree that the adequacy dimension and its indicator are very important for measuring the incidence of poverty and Why?

6. Do you agree with the views of pride and freedom dimensions are unimportant to measure the MPL?

7. Do you agree with the views of public service, gender equality, equality of law, and physical limitations of empowerment variable important to measure the MPL?

8. Do you agree with the views of access to credits, employment opportunity, access business training, access roads, access electricity and access to market, education, health, water, and sanitation of opportunity variable important to measure the MPL?

9. Do you agree with the views of public service, gender equality, equality of law, and physical limitations of empowerment variable important to measure the MPL?

10. Do you think the expenditure poverty above needs to be replaced with the MPL?

11. Do you think it is important to have a hierarchy of variables in developing the MPL measurement and policy formulation? 
Acknowledgements We are indebted to the Editor in Chief of Social Indicators Research, Professor Filomena Maggino, and the reviewers for their highly professional and constructive guidance to make this manuscript in better shape. The remaining errors are ours.

\section{References}

Alkire, S. (2011). Multidimensional poverty and its discontents [Paper Presentation]. In the 8th AFD-EUDN Conference, France.

Alkire, S. \& Santos, M.E. (2010). Acute multidimensional poverty: A new index for developing countries. OPHI Working Paper, 38: 1-15.

Alkire, S., \& Santos, M. E. (2013). A multidimensional approach: Poverty measurement \& beyond. Social Indicators Research, 112(2), 239-257.

Alkire, S., \& Foster, J. (2011). Counting and multidimensional poverty measurement. The Journal of Public Economics, 95(7-8), 476-487.

Alkire, S., \& Sumner, A. (2013). Multidimensional poverty and the Post-2015 MDGs. Devolepment, 56, 46-51.

Alsop, R. \& Heinsohn, N. (2005). Measuring empowerment in practice: Structuring analysis and framing indicators, World Bank Policy Working Paper 3510.

Anand, P., Hunter, G., Carter, I., Dowding, K., Guala, F., \& van Hees, M. (2009). The development of capability indicators. Journal of Human Development and Capabilities, 10(1), 125-152.

Artha, D., \& Dartanto, T. (2018). The multidimensional approach to poverty measurement in Indonesia: measurements determinants, and its policy implications. Journal of Economic Cooperation \& Development, 39(3), 1-38.

Suryahadi, A., Hadiwidjaja, G., Sumarto, S. (2012). Economic growth and poverty reduction in Indonesia before and after the Asian financial crisis, SMERU Working Paper, June 2012, 20.

Suryahadi, A., Al Izzati, R., Suryadarma, D. (2021). Dampak Pandemi COVID-19 terhadap Kemiskinan: Estimasi bagi Indonesia. https://webcache.googleusercontent.com/search?q=cache:naZNh_UHQDYJ: https://smeru.or.id/id/content/dampak-pandemi-covid-19-terhadap-kemiskinan-estimasi-bagi-indon esia $+\& \mathrm{~cd}=3 \& \mathrm{hl}=\mathrm{id} \& \mathrm{ct}=\mathrm{clnk} \& \mathrm{gl}=\mathrm{id}$, retrived, November 10, 2021.

Asian Development Bank. (2014). Poverty in Asia: A Deeper Look. ADB.

Asian Development Bank. (2021).COVID-19 Pushes 80 Million People In Asia Into Extreme Poverty: Asian Development Bank. https://www.ndtv.com/world-news/covid-19-pushes-80-million-people-inasia-into-extreme-poverty-asian-development-bank-2517263, retrieved, November 10, 2021.

Asra, A. (2019). Konsep dan ukuran Kemiskinan: Telaah Pustaka. In C. M. Firdausy (Ed.), Garis Kemikinan ECOPOS di Indonesia (pp. 10-22). LIPI Press.

Abuzar, A. (2011). Kemiskinan Perkotaan: Perkembangan, Determinan dan Strategi Pengentasannya [Unpublihsed manuscripts], Orasi Pengukuhan Profesor Riset, BPS/LIPI.

Abuzar, A. (2006). Book Review on J. Weiss (editor), Poverty Targeting in Asia, 2005. Asian Development Bank Institute and Edward Elgar Publishing.

Asra, A. (2000). Poverty and Inequality in Indonesia: Estimates, decomposition, and key issues. Journal of the Asia Pacific Economy, 5(1/2), 91-111.

Abuzar, A. (1993). Poverty issues in Indonesia: Recent development and challenges, Paper presented at the Indonesia Study Group Meeting, Canberra, ANU, 14 July.

Asra, A. \& Virola, R. (1992). Comparative study of poverty assessment: Indonesia and the Philippines, A report for Asian Development Bank (ADB).

Asrol, A., \& Ahmad, H. (2018). Analysis of factors that affect poverty in Indonesia. Revista Espacios, Vo, 39(45), 14-22.

Bambang, P. S., Brodjonegoro. (2020). Ekonomi Minim Kontak. Kompas, June 23, 2020, p. 6

Budiantoro. (2015). Penghitungan Indeks Kemiskinan Multidimensi Indonesia: 2012-2014. Prakarsa.

Rajab, B. (2017). Kemskinan Struktural dan Cara Penanggulangannya. http://pusdi-ebi.feb.unpad.ac.id/ kemiskinan-struktural-dan-cara-penanggulangannya/, retrieved August 20, 2020.

Clark, David. (2005). The capability approach: Its development, critiques, and recent advances. Global Poverty Research Group.

Central Board of Statiscs (2019). Kemiskinan di Indonesia, 2019. Berita Resmi Statistik, April, BPS.

Central Board of Statiscs (2021). Ekonomi Indonesia Triwulan 1 turun 0.74 persen. Berita Resmi Statistik, Mei, 2021, BPS.

Dolan, P., Layard, R., \& Metcalfe, R. (2011). Measuring subjective well-being for public policy. Office for National Statistics. 
Firdausy, C. M. (2012). Konsep dan Ukuran Kemiskinan Alternatif. P2E- LIPI.

Firdausy, C. M. (2013). Konsep dan Ukuran Kemiskinan Multi Dimensi. P2E-LIPI.

Firdausy, C. M. (2015). Can multidimensional poverty line be applied in Indonesia? Paper presented at the 3rd ADB-Asian Think Tank Development Forum, September 8-9, 2015, Kuala Lumpur.

Firdausy, C. M. (2016). One method to improve the official poverty line in Indonesia. Journal of Indonesian Social Sciences and Humanities, 6(1), 39-52.

Firdausy, C. M. (2017). Kemiskinan dan Disparitas Pendapatan di Indonesia, Kompas, p.6.

Firdausy, C.M. (2020). Garis Kemiskinan dan Kemiskinan ECOPOS. LIPI Press.

Foster, J., Greer, J., \& Thorbecke, E. (1984). A class of decomposable poverty measures. Econometrica, 52(3), 761-766.

Pramono, G., \& Marsisnoa, W. (2018). Availability of infrastructure for poverty in Indonesia: Spatial panel data analysis. Economics and Finance in Indonesia., 64(2), 157-180.

García-Pérez, C., González-González, Y., \& Prieto-Alaiz, M. (2017). Identifying the multidimensional poor in developed countries using relative thresholds: An application to Spanish data. Social Indicators Research, 131(1), 291-303.

Goedhart, T. (1977). The poverty line: Concept and measurement. The Journal of Human Resources, 13(4), 25-36.

Gustafsson, B. \& Ximing Yue. (2006). Rural people's perception of poverty in China, Discussion Paper No. 2486, The Institute for the Study of Labour (IZA).

https://www.cnbcindonesia.com/news/20200512174340-4-157993/bappenas-jumlah-orang-miskin-ri-tambah-2-juta-di-2020, retrieved July 30, 2020.

http://smeru.or.id/en/content/impact-covid-19-outbreak-poverty-estimation-indonesia, retrieved July 30, 2020.

https://blogs.worldbank.org/opendata/which-countries-reduced-poverty-rates-most, retrieved July 7, 2021.

KatadataIndonesia, 2020. Pengguna Smartphone diperkirakan Mencapai 89\% Populasi pada 2025. https:// databoks.katadata.co.id/datapublish/2020/09/15/pengguna-smartphone-diperkirakan-mencapai-89populasi-pada-2025. Pengguna Smartphone diperkirakan Mencapai 89\% Populasi pada 2025, retrieved July 10, 2021.

Knoema. (2020). China - Poverty headcount ratio at $\$ 3.2$ a day based on purchasing-power-parity in constant prices of 2011. https://knoema.com/atlas/China/Poverty-rate-at-national-poverty-line, retrieved July 7, 2021.

Li, G., Cai, Z., Liu, Ji., Liu, X., Su, S., Huang, X., \& Li, B. (2019). Multidimensional poverty in rural China: Indicators, spatiotemporal patterns, and applications. Social Indicators Research, 144(3), 1099-1134.

Lustig, N., \& Stern, N. (2000). Broadening the agenda for poverty reduction: Opportunity, empowerment Security. Finance and Development, 37(4), 25-36.

Kakwani, N. (2003). Issues in Setting Absolute Poverty Lines, Poverty, and Social Development. Paper, No. 3/June, ADB.

Ke-Mei, C., Chao-Hsien, L., \& Te-Mu, W. (2019). Measurement and determinants of multidimensional poverty: Evidence from Taiwan. Social Indicators Research: An International and Interdisciplinary Journal for Quality-of-Life Measurement, 145(2), 459-478.

Kingdon, G.G \& John Knight. (2004). Subjective well-being poverty versus income poverty and Capabilities poverty. Global Poverty Research Group.

Kompas. (2021). Iringi Bansos dengan Buka Lapangan kerja, Kompas National Daily Newspaper, February 16, 2021. p.1.

Lembaga Ilmu Pengetahuan Indonesia-LIPI. (2011). Faktor-Faktor Penyebab Kemiskinan di Indonesia. LIPI Press.

Mangahas, M. (2008). SWS monitoring of self-rated deprivation [Paper presented] at PIDS-NEDA-WORLD BANK Project on Comprehensive Documentation and Analysis of Issues on the Official Poverty Estimation Methodology of the Philippines, Manila.

Ma'ruf Amin. (2021). Strategi Penanggulangan Kemiskinan, Kompas, May 19, 2021, 6.

Ningrum, D. R., Taariq., R. M., Sagala, M., \& Aidha, C. N. (2019). Indeks Kemiskinan Multidimensi: Memotret Wajah-Wajah Kemiskinan di Indonesia. Prakarsa Policy Brief, 13: 1-4

Pomati, M., \& Nandy, S. (2020). Measuring multidimensional poverty according to national definitions: Operationalizing target 1.2 of the sustainable development goals. Social Indicators Research, 148, 105-126.

Ravallion, M. (1992). Poverty Comparisons: A Guide to Concepts and Methods. World Bank.

Ridho Al Izzati. (2021). Situasi Kemiskinan Saat pandemi. https://webcache.googleusercontent.com/search? q=cache:ZZkYM51iyc0J:https://smeru.or.id/id/content/situasi-kemiskinan-selama-pandemi+\&cd=2\& $\mathrm{hl}=\mathrm{id} \& \mathrm{ct}=\mathrm{clnk} \& \mathrm{gl}=\mathrm{id}$, retrieved, November 17, 2021. 
Ridwan. M, (2019). Indonesia harus Gunakan Indikator Kemiskinan Multidimensi.https://www.kompa siana.com/ridwan78/56c0bb901bafbd720b803f33/indonesia-harus-gunakan-indikator-kemiskinanmultidimensi?page=all, uploaded on November 16, 2019.

Sen, A. (1999). Development as Freedom, Anchors Books.

Simanjutak, S. Y., Supriatna, T., Adiwisastra, J., Sulistiyani, D., \& Firdausy, C. M. (2019). Determinant factors affecting the performance of health services of the community health service centre in Indonesia. Journal of Applied Economic Sciences, 4(66), 1021-1028.

Suyanto, B. (2013). Anatomi Kemiskinan dan Strategi Penanganannya. In-TANS Publishing.

Tasmilah. (2021). Kemiskinan Multidimensi, Harian republika, July 16, 2021.p. 7.

Tsui, K. Y. (2002). Multidimensional poverty indices. Social Choice Welfare, 19, 69-93. https://doi.org/10. 1007/s355-002-8326-3

Van Praag, Benard \& Carbonnel, A.F. (2006). A Multi-dimensional Approach to Subjective Poverty [Paper presented at the conference on The measurement of Multidimensional Poverty: Theory and Evidence, World Bank, Brazil.

World Bank. (2001). World Development Report 2000/2001: Attacking Poverty. Oxford University Press.

World Bank. https://openknowledge.worldbank.org/handle/10986/11856 License: CC BY 3.0 IGO.

World Bank. (2006). Making the New Indonesia Work for the Poor. The World Bank.

World Bank. ( 2020). Indonesia Economic Prospects, December 2020: Towards a Secure and Fast Recovery. World Bank, Washington, DC. (C) World Bank. https://openknowledge.worldbank.org/handle/ 10986/34930 License: CC BY 3.0 IGO."

Publisher's Note Springer Nature remains neutral with regard to jurisdictional claims in published maps and institutional affiliations. 